REALA, número 14, octubre de 2020

Sección: ARTÍCULOS

Recibido: 23-04-2020

Modificado: 03-07-2020

Aceptado: 04-07-2020

DOI: https://doi.org/10.24965/reala.i14.10796

Páginas: 29-48

\title{
Los efectos jurídicos de la omisión del trámite de consulta pública previa en el procedimiento de elaboración de las disposiciones administrativas de carácter general: ¿nulidad de pleno derecho de la norma aprobada?
}

\section{The legal effects of omitting the initial public consultation process in the procedure for drafting general administrative provisions: invalidity ab initio of the approved rule?}

\author{
Lucía Casado Casado \\ Universidad Rovira i Virgili (España) \\ ORCID: https://orcid.org/0000-0001-5603-3264 \\ lucia.casado@urv.cat
}

\section{NOTA BIOGRÁFICA}

Doctora en Derecho por la Universidad Autónoma de Barcelona. Profesora Titular de Derecho Administrativo de la Universidad Rovira i Virgili (URV). Investigadora del Centro de Estudios de Derecho Ambiental de Tarragona (CEDAT). Miembro del Grupo de investigación de la URV "Territorio, Ciudadanía y Sostenibilidad", reconocido como Grupo de investigación consolidado por la Generalitat de Catalunya, y también del Grupo de investigación de la URV de estudios jurídicos locales. Entre sus líneas de investigación destacan las siguientes: derecho local; jurisdicción contencioso-administrativa; mejora regulatoria y potestad normativa; procedimiento administrativo; expropiación forzosa; derecho audiovisual; derechos sociales; y derecho ambiental administrativo.

\section{RESUMEN}

La aprobación de la Ley 39/2015, de 1 de octubre, del Procedimiento Administrativo Común de las Administraciones Públicas, supone la introducción de un nuevo trámite de consulta pública previa en el procedimiento de elaboración de normas con rango legal y reglamentario, regulado en su artículo 133. Este trámite, de carácter preceptivo, refuerza la participación ciudadana, al garantizarse en una fase muy temprana, previa al procedimiento normativo en sentido propio, cuando todavía no existe una propuesta redactada del proyecto o anteproyecto de ley o de reglamento y todas las opciones están abiertas. Sin embargo, nada dice este precepto sobre los efectos jurídicos que se anudan a la omisión -o práctica inadecuada- de la consulta pública previa, a pesar de ser ésta una cuestión de gran relevancia y que, en el fondo, determina la efectividad real de este trámite. Sobre esta cuestión versa este trabajo que, ante el silencio de la LPACAP, pretende aportar herramientas a los operadores jurídicos que ilustren sobre cuáles deben ser los efectos jurídicos de la omisión de este trámite en el procedimiento de elaboración de normas reglamentarias. Con este fin, se analizan tanto las diferentes interpretaciones ofrecidas por la doctrina como la jurisprudencia recaída hasta el momento.

\section{PALABRAS CLAVE}

Disposiciones administrativas de carácter general; procedimiento administrativo; participación ciudadana; consulta pública previa; nulidad de pleno derecho. 


\begin{abstract}
The passing of Spanish Law 39/2015, of 1 October, on Common Administrative Procedures for Government Administrations introduced a new public consultation procedure that must take place prior to the drafting of legal rules with legal and regulatory status, as established under its section 133 . That mandatory procedure enhances public participation because it occurs during a very early phase when all options are still open, prior to the initiation of the actual legislative process and before any draft versions of laws or regulations have been produced. However, the Law does not address the legal effects resulting from the omission -or improper exercise- of that initial public consultation, despite the significance of the matter as a factor that fundamentally determines the actual effectiveness of the procedure. This article addresses this issue in view of its absence from the legislation and in an effort to provide those working in the field of law with tools to help determine the legal effects of the omission of that procedure during development of laws and regulations. To this end, the various interpretations offered in the literature and in existing case law are analysed.
\end{abstract}

\title{
KEYWORDS
}

General administrative provisions; administrative procedure; public participation; initial public consultation; invalidity ab initio.

\section{SUMARIO}

INTRODUCCIÓN. 1. LA AUSENCIA EN LA LPACAP DE REGULACIÓN DE LOS EFECTOS DE LA OMISIÓN DEL TRÁMITE DE CONSULTA PÚBLICA PREVIA EN EL PROCEDIMIENTO DE ELABORACIÓN DE DISPOSICIONES ADMINISTRATIVAS DE CARÁCTER GENERAL Y LAS DUDAS SUSCITADAS. 2. LAS DIFERENTES POSICIONES DOCTRINALES EN TORNO A LOS EFECTOS DE LA OMISIÓN DEL TRÁMITE DE CONSULTA PÚBLICA PREVIA. 3. LOS PRIMEROS PRONUNCIAMIENTOS JURISPRUDENCIALES SOBRE LOS EFECTOS DE LA OMISIÓN DEL TRÁMITE DE CONSULTA PÚBLICA PREVIA. 3.1. LAS PRIMERAS SENTENCIAS DEL TRIBUNAL SUPREMO. 3.2. LAS PRIMERAS SENTENCIAS DE LOS TRIBUNALES SUPERIORES DE JUSTICIA DE LAS COMUNIDADES AUTÓNOMAS. 3.2.1. Las Sentencias del Tribunal Superior de Justicia de Aragón núm. 126/2019 y núm. 127/2019, de 28 de marzo de 2019: efectos de la omisión del trámite de consulta pública previa en el procedimiento de elaboración de reglamentos autonómicos. 3.2.2. La Sentencia del Tribunal Superior de Justicia de Navarra núm. 88/2019, de 10 de abril de 2019: efectos de la omisión del trámite de consulta pública previa en el procedimiento de elaboración de reglamentos autonómicos. 3.2.3. La Sentencia del Tribunal Superior de Justicia de Cataluña núm. 588/2019, de 28 de junio de 2019: efectos de la omisión del trámite de consulta pública previa en el procedimiento de elaboración de reglamentos autonómicos. 3.2.4. Las Sentencias del Tribunal Superior de Justicia de Castilla y León. A) La Sentencia núm. 574/2018, de 14 de junio de 2018: efectos de la omisión del trámite de consulta pública previa en el procedimiento de elaboración de ordenanzas fiscales. B) Las Sentencias núm. 1054/2018, de 22 de noviembre de 2018, núm. 1055/2018, de 23 de noviembre de 2018, núm. 1060/2018, de 23 de noviembre de 2018 y núm. 1067/2018, de 26 de noviembre de 2018: efectos de la práctica inadecuada del trámite de consulta pública previa en el procedimiento de elaboración de reglamentos autonómicos. 3.2.5. Las Sentencias del Tribunal Superior de Justicia de Asturias núm. 34/2019, de 28 de enero de 2019, y del Tribunal Superior de Justicia de Galicia núm. 75/2020, de 14 de febrero de 2020: efectos de la omisión del trámite de consulta pública previa en el procedimiento de elaboración de ordenanzas fiscales. CONSIDERACIONES FINALES. REFERENCIAS BIBLIOGRÁFICAS.

\section{INTRODUCCIÓN}

La Ley 39/2015, de 1 de octubre, del Procedimiento Administrativo Común de las Administraciones Públicas, incluye un Título VI (arts. 127 a 133), dedicado a la iniciativa legislativa y a la potestad para dictar reglamentos y que se inscribe en la política de mejora de la regulación impulsada por la Organización para la Cooperación y el Desarrollo Económico y por la Unión Europea. Entre las grandes novedades que aporta este Título debe destacarse la nueva regulación del artículo 133, destinado a regular la participación de los ciudadanos en el procedimiento de elaboración de normas con rango de ley y reglamentos y que «supone, en su conjunto, un avance muy notable en términos participativos, que sitúa a España en la línea de las experiencias más avanzadas en la materia» (Mir, 2017: 234). Desde la perspectiva de la participación ciudadana, este precepto da un paso importante, habida cuenta de que incorpora, con carácter preceptivo, un 
REALA. Nueva Época - N.o 14, octubre 2020 - ISSN: 1989-8975 - DOI: https://doi.org/10.24965/reala.i14.10796 - [Págs. 29-48]

Los efectos jurídicos de la omisión del trámite de consulta pública previa en el procedimiento de elaboración de las disposiciones..

nuevo trámite participativo: la consulta pública previa, que tiene lugar en una fase temprana, cuando todavía no se ha elaborado el proyecto correspondiente y con la que se inicia el ciclo normativo (Velasco, 2019: 315). Se pretende con ello «obtener una participación eficaz y real sobre el futuro texto, en el entendimiento de que el mismo aún no ha sido elaborado» (Galán, 2020: 160). De este modo, la participación se produce desde la gestación de la norma, antes que exista una propuesta normativa redactada, a diferencia de lo que venía siendo práctica habitual hasta la entrada en vigor de la LPACAP (Casado, 2018: 165). Además, con la inclusión de este trámite también se ensancha el control de la potestad reglamentaria de la administración pública (Cierco y Ropero, 2017: 107-108).

A pesar de la relevancia de este trámite, su regulación sustantiva en la LPACAP es parca (Velasco, 2019: 315), limitándose esta Ley a recoger algunas escasas previsiones, en sus apartados 1 y 3 , sobre su contenido y forma de realización y los destinatarios de este trámite; y, en su apartado 4, sobre las posibles excepciones a su aplicación. Además, con arreglo a la jurisprudencia constitucional ${ }^{1}$, únicamente son básicos y no son contrarios al orden constitucional de competencias, resultando de aplicación a los reglamentos de las comunidades autónomas, el inciso «Con carácter previo a la elaboración del proyecto o anteproyecto de ley o de reglamento, se sustanciará una consulta pública», de su apartado 1; y las excepciones recogidas en el párrafo primero de su apartado 4. Las previsiones restantes sobre la consulta pública recogidas en el artículo 133 de la LPACAP son parcialmente inconstitucionales y, por ello, únicamente aplicables directamente a la elaboración de reglamentos estatales, siendo inaplicables directamente a la elaboración de reglamentos autonómicos y a las ordenanzas locales (Velasco, 2019: 314)².

No debe extrañar, por tanto, que, dada la parquedad normativa existente, sean muchas las cuestiones que suscita la aplicación de este trámite, por ejemplo, con relación al alcance y la extensión con que se configura, el plazo en que debe realizarse, la forma en que debe sustanciarse o cuáles deben ser sus destinatarios, por citar solo algunos ejemplos. Sin embargo, entre estas cuestiones, hay una, a nuestro entender, especialmente importante, por cuanto no está resuelta en la LPACAP y suscita importantes dudas: la de los efectos jurídicos que conlleva la omisión -o práctica inadecuada- de este trámite en el procedimiento de elaboración de disposiciones administrativas de carácter general y, en particular, si conlleva o no la nulidad de pleno derecho de la norma aprobada.

En el análisis de esta cuestión se centra este estudio, que, ante el silencio de la LPACAP, pretende aportar herramientas a los operadores jurídicos que ilustren sobre cuáles deben ser los efectos jurídicos de la omisión de este trámite en el procedimiento de elaboración de normas reglamentarias. Con este fin, se analizan tanto las diferentes interpretaciones ofrecidas por la doctrina administrativista como la jurisprudencia dictada hasta el momento, tanto por el Tribunal Supremo como por los Tribunales Superiores de Justicia de las Comunidades Autónomas.

\section{LA AUSENCIA EN LA LPACAP DE REGULACIÓN DE LOS EFECTOS DE LA OMISIÓN DEL TRÁMITE DE CONSULTA PÚBLICA PREVIA EN EL PROCEDIMIENTO DE ELABORACIÓN DE DISPOSICIONES ADMINISTRATIVAS DE CARÁCTER GENERAL Y LAS DUDAS SUSCITADAS}

En nuestro ordenamiento jurídico, la exigencia de consulta pública previa en el procedimiento de elaboración de disposiciones administrativas de carácter general se configura en términos muy amplios. Con arreglo al artículo 133.1 de la LPACAP, este trámite debe sustanciarse con carácter previo a la elaboración de cualquier proyecto o anteproyecto de ley o de reglamento ${ }^{3}$. Sin embargo, el alcance de este trámite debe ser relativizado, habida cuenta de que son muchos los supuestos en que puede ser excepcionado. En efecto, el

Vid. la Sentencia del Tribunal Constitucional 55/2018, de 24 de mayo de 2018 (ponente: Andrés Ollero Tassara). Sobre los efectos de esta Sentencia en el procedimiento de elaboración de reglamentos autonómicos, vid. ARAGUÀS (2019: 101-104); y sobre sus efectos en el procedimiento de elaboración de reglamentos locales, vid. VELASCO (2019: 306-314). En relación con el impacto de la LPACAP en el procedimiento de elaboración de normas reglamentarias locales vid. CASADO (2017: 87-141), GARCÍA (2017: 83-131), PRIETO (2019: 1-39) y VELASCO (2019: 299-349). Y, en general, sobre la incidencia de la LPACAP (y también de la Ley 40/2015, de 1 de octubre, de régimen jurídico del sector público) sobre el derecho local, vid. GARCíA (2020: 37-50).

2 Nótese que, como advierte VELASCO (2019: 312 y 314), los preceptos del Título VI que no son directamente aplicables a las comunidades autónomas y a las entidades locales sí son aplicables de forma supletoria, en virtud del artículo 149.3 de la CE.

3 Sobre el alcance de la exigencia de la consulta pública previa y las excepciones, vid., entre otros, ARAGUÀS (2016: 103-104), CASADO (2018: 179-193), FERNÁNDEZ (2020: 223-228) y VELASCO (2019: 317-321). 
REALA. Nueva Época - N. ${ }^{0}$ 14, octubre 2020 - ISSN: 1989-8975 - DOI: https://doi.org/10.24965/reala.i14.10796 - [Págs. 29-48]

Los efectos jurídicos de la omisión del trámite de consulta pública previa en el procedimiento de elaboración de las disposiciones..

Lucía Casado Casado

artículo 133.4 de la LPACAP recoge algunas excepciones que pueden agruparse en supuestos de exclusión por razón de la materia y por el alcance de la regulación pretendida (Velasco, 2019: 317). Entre los primeros, se incluyen los previstos en su párrafo primero -no tachado de inconstitucionalidad por la Sentencia 55/2018 y, por lo tanto, aplicable a los reglamentos de todas las administraciones públicas-, que permite prescindir de este trámite «en el caso de normas presupuestarias u organizativas de la Administración General del Estado, la Administración autonómica, la Administración local o de las organizaciones dependientes o vinculadas a éstas, o cuando concurran razones graves de interés público que lo justifiquen». Y, entre los segundos, recogidos en su párrafo segundo -declarado inconstitucional para las comunidades autónomas, por desbordar el alcance de lo básico, y no aplicable a los reglamentos autonómicos ${ }^{4}$-, se incluye la posibilidad de omitir este trámite "Cuando la propuesta normativa no tenga un impacto significativo en la actividad económica, no imponga obligaciones relevantes a los destinatarios o regule aspectos parciales de una materia». En este caso, el criterio de la excepción no es el tipo de normas, sino sus efectos (Velasco, 2019: 317). Asimismo, este párrafo prevé que «Si la normativa reguladora del ejercicio de la iniciativa legislativa o de la potestad reglamentaria por una Administración prevé la tramitación urgente de estos procedimientos, la eventual excepción del trámite por esta circunstancia se ajustará a lo previsto en aquella». Por lo tanto, estamos ante un trámite preceptivo, exigido en el procedimiento administrativo de elaboración de disposiciones de carácter general, aunque con numerosas vías de excepción ${ }^{5}$, cuya concurrencia deberá ser debidamente motivada y justificada. Se trata, en consecuencia, de un trámite que debe darse a menos que concurran las excepciones legalmente establecidas.

De este modo, salvo que se justifique adecuadamente la concurrencia de alguna de las excepciones, existe, con arreglo al artículo 133, apartados 1 y 4, de la LPACAP, un deber general de consulta pública (Velasco, 2019: 321), con carácter previo al procedimiento normativo en sentido estricto y a la redacción del proyecto o anteproyecto de reglamento. Por lo tanto, este trámite «deberá efectuarse en todo caso (salvo expresa motivación y justificación de las razones que avalan su no sometimiento)» (Galán, 2020: 161).

Llama la atención, sin embargo, que, a pesar de lo novedoso de este trámite incorporado por la LPACAP y del gran avance que supone desde la perspectiva de la participación ciudadana en el procedimiento de elaboración de normas, en aras a conseguir una participación real y efectiva sobre el futuro texto normativo -cuando aún no hay una propuesta redactada y todas las opciones están abiertas-, ninguna previsión se incluya en la LPACAP en torno a las consecuencias que se derivan de su omisión o de su deficiente realización en el procedimiento de elaboración de disposiciones administrativas de carácter general. En efecto, nada dice la LPACAP sobre los efectos jurídicos asociados a la omisión o insuficiencia de la consulta pública previa.

A la vista de esta omisión, son muchos los interrogantes y las dudas que se suscitan. Ciertamente, el artículo 47.2 de la LPACAP prevé que «serán nulas de pleno derecho las disposiciones administrativas que vulneren la Constitución, las leyes u otras disposiciones administrativas de rango superior, las que regulen materias reservadas a la Ley, y las que establezcan la retroactividad de disposiciones sancionadoras no favorables o restrictivas de derechos individuales». Además, no se admite la anulabilidad para las disposiciones administrativas de carácter general, con relación a las cuales la invalidez despliega sus efectos en su grado máximo. Por lo tanto, parece que el incumplimiento de lo dispuesto en el artículo 133 de la LPACAP en relación con la consulta pública previa debería generar la nulidad de pleno derecho de la norma reglamentaria estatal, autonómica o local que se apruebe sin haberse realizado la preceptiva consulta pública previa o habiéndose realizado de forma insuficiente, sin atenerse a lo establecido en la normativa vigente. Ahora bien, ¿se aplicaría el artículo 47.2 de la LPACAP y, por lo tanto, la nulidad de pleno derecho como efecto jurídico invalidante, en todos los supuestos de omisión o insuficiente realización de este trámite?

4 Como advierte VELASCO (2019: 311), el artículo 133.4, párrafo segundo, es inconstitucional para las comunidades autónomas, pero no lo es (y sí es aplicable) a los reglamentos estatales. «Por eso la declaración de inconstitucionalidad es parcial y no lleva aparejada la declaración de nulidad. Es este uno de los casos en que inconstitucionalidad y nulidad no van a la par». Tampoco sería, en nuestra opinión, directamente aplicable a los entes locales, por desbordar el alcance de lo básico, aunque nada diga el Tribunal Constitucional al respecto. En este mismo sentido, VELASCO (2019: 312 y 317), en cuya opinión los preceptos del Título VI de la LPACAP que no son directamente aplicables a las entidades locales sí pueden ser aplicables de forma supletoria.

5 Como ponen de manifiesto CIERCO y ROPERO (2017: 123-124), «existe un catálogo muy amplio de razones a las que acogerse para "esquivar" la nueva consulta pública»; en su opinión, «las excepciones a la consulta pública acusan en su formulación importantes limitaciones. La más relevante de todas ellas es que las aperturas, sumadas todas ellas, abren un agujero demasiado grande». En definitiva, para CIERCO y ROPERO (2017: 125), «la generosidad del art. 133.4 de la LPAC puede descubrir, inesperadamente, una vía de salida para aquellas Administraciones menos provistas y capacitadas organizativa y tecnológicamente». En sentido similar, CASADO (2018: 168). 
REALA. Nueva Época - N. ${ }^{0}$ 14, octubre 2020 - ISSN: 1989-8975 - DOI: https://doi.org/10.24965/reala.i14.10796 - [Págs. 29-48]

Los efectos jurídicos de la omisión del trámite de consulta pública previa en el procedimiento de elaboración de las disposiciones..

¿Cabe alguna excepción? En definitiva, cabe preguntarse, sobre las consecuencias que se derivarían de la aprobación de una norma sin haberse sustanciado el trámite de consulta pública previa ¿Sería una norma nula de pleno derecho? Igualmente, cabe plantear qué consecuencias se derivarían de la aprobación de una norma, habiéndose realizado este trámite, pero de forma inadecuada, sin atenerse a lo previsto en la LPACAP - por ejemplo, si no se hace con carácter previo a la elaboración del proyecto o anteproyecto de reglamento o si se hace durante un plazo insuficiente o no dirigiéndola a las personas a quienes debiera dirigirse ${ }^{6}$ - ¿ ¿También sería nula de pleno derecho la norma aprobada? A estos interrogantes que la LPACAP deja abiertos se añaden otros. El fundamental es si la omisión -o insuficiencia- de la consulta pública previa puede ser subsanada posteriormente, si se realizan adecuadamente los trámites de audiencia e información públicas ¿Se trata de un trámite subsanable? O ¿resulta inadmisible que la realización posterior de estos trámites participativos subsane el incumplimiento del deber de consulta pública previa? Señala Casado (2018: 199) que «la omisión de este trámite debe tener consecuencias jurídicas y no debe tratarse de una mera formalidad. De no ser así, se estaría privando de toda eficacia a un trámite que, como hemos podido ver a lo largo de este trabajo, supone un refuerzo importante de la participación ciudadana, al permitirla en una fase temprana, cuando las posiciones todavía no están bien definidas ni las decisiones tomadas y todavía hay margen para incorporar observaciones y sugerencias». Sin embargo, nada dice la LPACAP al respecto y la inseguridad jurídica está servida, máxime al ser un trámite introducido con carácter general por vez primera en la LPACAP y no contar con experiencia previa.

Como puede advertirse, son muchos los interrogantes y las dudas que suscita el silencio de la LPACAP en relación con los efectos jurídicos invalidantes asociados a la omisión -o inadecuada realización- del trámite de consulta pública. Inevitablemente, esta situación lleva aparejada inseguridad jurídica para los operadores jurídicos y genera numerosas interpretaciones posibles. Sin duda, lo deseable hubiera sido incluir una previsión al respecto en la LPACAP. Así, se hubiera ganado en seguridad jurídica. Pero la situación es la que es y carecemos de esta previsión. Ello nos obliga, como juristas, a intentar aportar soluciones a los interrogantes planteados. Desde la doctrina administrativista no han faltado posicionamientos al respecto y argumentos que justifican la respuesta a las preguntas planteadas en uno $u$ otro sentido. Tales posiciones serán objeto de análisis a continuación. Pero nuestro análisis no puede detenerse aquí y hace falta también indagar en la jurisprudencia, con el fin de ver si existen ya algunos criterios fijados al respecto que confieran seguridad jurídica a una cuestión que genera numerosas dudas. Resulta fundamental clarificar los efectos jurídicos anudados a la omisión -o insuficiencia- de la consulta pública previa. Como han puesto de manifiesto Cierco y Ropero (2017: 125), el régimen de invalidez es un riesgo que «amenaza el cabal afianzamiento de la consulta previa. El grado de tensión que se aplique al reglamento aprobado sin consulta o con una consulta sustancialmente inadecuada determinará la agudeza del nuevo trámite». Se trata, por tanto, de cuestiones de enorme relevancia a las cuales debe darse una adecuada respuesta que ayude a dotar de seguridad jurídica la realización de este trámite.

Veamos, a continuación, las respuestas dadas por la doctrina administrativista y por la jurisprudencia recaída hasta el momento.

\section{LAS DIFERENTES POSICIONES DOCTRINALES EN TORNO A LOS EFECTOS DE LA OMISIÓN DEL TRÁMITE DE CONSULTA PÚBLICA PREVIA}

El silencio de la LPACAP en torno a los efectos de la omisión o insuficiencia del trámite de consulta pública previa en el procedimiento de elaboración de disposiciones de carácter general obliga a los operadores jurídicos a realizar interpretaciones al respecto, con el fin de determinar si la ausencia de este trámite puede o no generar la nulidad de pleno derecho de una norma reglamentaria. Desde el primer momento, la doctrina administrativista se ha pronunciado al respecto, si bien las opiniones vertidas no son en absoluto unánimes. Hay dos posiciones claramente diferenciadas: una primera, que defiende la invalidez y, por consiguiente, la nulidad de pleno derecho de la disposición de carácter general en cuyo procedimiento de elaboración se haya omitido o realizado de forma sustancialmente inadecuada este trámite; y una segunda, mucho más flexible, que relativiza la eficacia invalidante de estos vicios y sostiene que tal omisión no acarrea, en todo caso, la nulidad de pleno derecho de la norma.

$6 \quad$ Al respecto, vid. CASADO (2018: 198-199). 
REALA. Nueva Época - N. ${ }^{0}$ 14, octubre 2020 - ISSN: 1989-8975 - DOI: https://doi.org/10.24965/reala.i14.10796 - [Págs. 29-48]

Los efectos jurídicos de la omisión del trámite de consulta pública previa en el procedimiento de elaboración de las disposiciones..

Son partidarios de la primera posición Antelo (2016: 117-118), Araguàs (2017: 492-493), Campos (2016: 603-604), Casado (2018: 201-203), Cierco y Ropero (2017: 126-127), Fernández (2020: 223-224), Galán (2020: 159-163) y Mora (2016: 560-561). Araguàs (2017: 492-493) parte de que la omisión de la consulta previa cuando es preceptiva es un defecto procedimental difícilmente subsanable a posteriori, por lo que su no realización obligaría a iniciar de nuevo el procedimiento de elaboración. De no hacerlo, en su opinión, «la consecuencia lógica sería la nulidad de la norma, aunque se podría valorar si, habiéndose llevado a cabo la consulta previa en un momento tardío, los términos en los que se ha realizado dicho trámite han permitido cumplir su finalidad» ${ }^{7}$. En consecuencia, considera que «la realización de los trámites participativos sin poner a disposición de los ciudadanos la información indicada (o incluso hacerlo en un plazo excesivamente breve) es un defecto en la realización de los trámites participativos que, a nuestro juicio, acarrea la nulidad de la norma cuando ello incida de manera efectiva en el texto finalmente aprobado». En la misma línea, se sitúa Casado (2018: 201-203), que aboga por que la ausencia del trámite de consulta pública previa sea considerada como causa de nulidad de pleno derecho de las disposiciones de carácter general, salvo que dicha omisión esté amparada en una de las causas de excepción previstas en la normativa y esté debidamente justificada y motivada en el expediente. Para esta autora, «ésta es la solución más coherente, si realmente quiere dotarse de efectividad al trámite de consulta pública previa y potenciar la participación ciudadana en el procedimiento de elaboración de normas en una fase temprana». Según su parecer, este trámite no puede quedar subsanado con la práctica posterior de la audiencia y la información pública, ya que, «precisamente la peculiaridad más destacable de este trámite participativo y que le da sentido frente a los otros dos mencionados es el momento temporal en que se produce, ya que tiene lugar con carácter previo a la elaboración del proyecto normativo, cuando todas las opciones están abiertas, y no inmediatamente antes de la aprobación de la norma, cuando ya se ha completado prácticamente su tramitación, como sucede con la audiencia y la información pública. Además, las cuestiones sobre las que versa la consulta pública previa y que constituyen su objeto (recabar la opinión de los ciudadanos, cuando todas las opciones están aún abiertas, sobre los problemas que se pretenden solucionar con la iniciativa, la necesidad y oportunidad de su aprobación, los objetivos de la norma y las posibles soluciones alternativas regulatorias y no regulatorias), ya no tendría sentido plantearlas en los trámites de audiencia e información pública». Muy similares son los argumentos proporcionados por Cierco y Ropero (2017: 126-127), que, partiendo del carácter esencial de este trámite en el iter reglamentario, consideran defendible la extensión a este ámbito de la sanción propia de los trámites participativos clásicos -audiencia e información públicas-. Por ello, afirman que «La omisión de la consulta pública, o su práctica desviada, constituye un vicio que invalida la disposición reglamentaria y, en consecuencia, se erige en razón para justificar su expulsión del ordenamiento jurídico. El argumento a simili parece intachable: si la ley procedimental no distingue en el carácter preceptivo, esencial, de los trámites de consulta, audiencia e información pública del procedimiento de creación de normas reglamentarias, sus vicios deben contar con un mismo tratamiento jurídico. Cobra aquí, pues, mucha importancia no solo la significación del trámite y la cobertura que presta a una vertiente inédita del principio participativo, sino, sobre ello, la fortaleza que la ley le concede al hacer de la consulta un paso preceptivo en el itinerario. Y es que el art. 133 de la LPAC no incorpora un mandato programático que interpele sobre una anticipación temporal de la participación activa de la sociedad; lo que introduce es, sin ambages, un trámite imperativo». Para Cierco y Ropero (2017: 127), a esta tesis, se suma, como contrafuerte, la fuerza del catálogo de excepciones que permiten excepcionar la exigencia de consulta pública previa. En su opinión, «A mayores excepciones tipificadas, mayor confirmación de la regla: exceptio probat regulam in casibus non exceptis». En la misma línea, Fernández (2020: 223-224) considera que la omisión de la consulta pública previa supone un vicio que invalida la disposición reglamentaria con el grado máximo de invalidez -la nulidad de pleno derecho-, al no operar en las disposiciones normativas el régimen de anulabilidad. También Galán (2020: 163), en cuya opinión la intención del legislador es clara en cuanto a través de la consulta pública se pretenden ampliar las posibilidades de participación de la ciudadanía en el seno del procedimiento, por lo que la consecuencia lógica de su omisión es «el carácter invalidante de una actuación municipal que sin la debida justificación y motivación al expediente (art. 70 LPACAP) avale el prescindir de un trámite preceptivo con carácter general».

Al respecto, señala ARAGUÀS (2017: 492, nota al pie 13) que «En el sistema estadounidense, en ocasiones se ha admitido la validez de los reglamentos sin realizar el trámite de comment en el momento oportuno sobre la base de una doctrina que tiene en cuenta la falta de efectos perjudiciales que se haya derivado de esta circunstancia (harmless error). Entre otras cuestiones, los tribunales han valorado si las cuestiones planteadas en el trámite participativo podían resolverse, o no, con una pluralidad de alternativas; sí o sí la agencia se había mostrado receptiva a cambiar el contenido de la norma». 
REALA. Nueva Época - N.o 14, octubre 2020 - ISSN: 1989-8975 - DOI: https://doi.org/10.24965/reala.i14.10796 - [Págs. 29-48]

Los efectos jurídicos de la omisión del trámite de consulta pública previa en el procedimiento de elaboración de las disposiciones..

Por su parte, Campos (2016: 603-604) y Mora (2016: 560-561), a la hora de analizar los efectos de la omisión de este trámite sobre la norma afectada, cuando fuera preceptivo, ponen el acento en la relevancia que la jurisprudencia está confiriendo a la omisión de los trámites que hacen posible la participación ciudadana, en el sentido de poder sancionarse con la nulidad de pleno derecho de la disposición. Así, Mora (2016: 560-561) señala que puede reconocerse la consolidación de una línea jurisprudencial «en cuya virtud el trámite de audiencia o el de información pública es fundamental en la elaboración del reglamento, acarreando la mayoría de las veces la nulidad de pleno derecho». Y Campos (2016: 603-604) recuerda «su vinculación con un derecho reconocido constitucionalmente, y la creciente relevancia que la participación ciudadana ha adquirido en nuestro ordenamiento jurídico tras la aprobación de la normativa en materia de transparencia, tanto la ley estatal básica como las distintas regulaciones autonómicas, desarrollando ampliamente la dimensión activa de la participación ciudadana». También Antelo (2016: 117-118) pone de relieve que la inobservancia de este trámite puede invalidar la norma reglamentaria aprobada, advirtiendo que sería posible la impugnación, a través de un recurso contencioso-administrativo directo contra una ordenanza o reglamento local por omisión del procedimiento de elaboración normativa o de alguno de sus trámites esenciales, pero señalando las dificultades de plantear un recurso indirecto utilizando como fundamento las infracciones procedimentales en que se hubiera podido incurrir.

Por el contrario, son partidarios de la segunda posición Messeguer (2016: 133), Prieto (2016: 359-360) y Velasco (2019: 322-323). Messeguer (2016: 133) otorga menor entidad a las consecuencias derivadas de la omisión del trámite de consulta pública. Según su parecer, «es evidente que el medio a través del que se efectúa la consulta (portal web de la Administración competente -no se menciona "sede electrónica"-), su objetivo (recabar la "opinión" de los sujetos y organizaciones más representativas potencialmente afectados por la futura norma) y las posibilidades de prescindir de él (mayores que para el trámite de audiencia) pueden ser factores determinantes a la hora de concluir la eventual menor entidad de su ausencia sobre la validez de la norma. Bien es cierto, sin embargo, que la categoría de la anulabilidad es desconocida cuando de disposiciones de carácter general se trata (artículo 48 de la LPAC), aunque la jurisprudencia ha venido analizando cuidadosa y detenidamente, caso por caso, las consecuencias menos graves que pueden tener algunas infracciones procedimentales ocurridas a lo largo del procedimiento de elaboración de las normas». Prieto (2016: 359-360), considerando que el trámite de consulta pública es previo al propio procedimiento de elaboración de la disposición administrativa y que su finalidad puede alcanzarse a través de otros trámites similares posteriores -como el trámite de audiencia o información públicas-, donde los ciudadanos podrán pronunciarse sobre la necesidad y la oportunidad de la concreta norma proyectada, de la existencia o no de alternativas no regulatorias..., concluye que «su omisión no constituirá una inobservancia trascendente que afecte a la finalidad perseguida por la norma, siempre que se haya realizado a través del trámite de audiencia o información públicas, pues así se habrá logrado su finalidad a pesar de dicha omisión». Admite, pues, la posibilidad de subsanar este vicio procedimental. Es más, considera que se trata propiamente de un trámite duplicado del trámite de audiencia e información pública. Por ello, le parece razonable «entender conforme al principio de eficacia administrativa y de economía procesal que la omisión de ese trámite no constituirá una "inobservancia trascendente", siempre y cuando quede subsanado mediante la práctica posterior del trámite de audiencia e información públicas». Esta posibilidad de subsanación con la posterior realización de los trámites de audiencia e información pública es rechazada, en cambio, por Velasco (2019: 323$)^{8}$, en cuya opinión son trámites independientes y distintos del deber de consulta previa, por lo que su realización no subsana el incumplimiento del deber de consulta. Subraya este autor la caracterización legal de la consulta pública como «previa», antecedente al procedimiento normativo en sentido propio, y sostiene, como punto de partida, que «por sí sola la omisión de la consulta previa no determina la nulidad de la ordenanza», aunque sí puede ser relevante para la valoración de otros posibles defectos materiales o procedimentales de la ordenanza final. Así, considera que «la omisión de la consulta previa coadyuva a un posible juicio de arbitrariedad ${ }^{10}$ (ilícita ex art. 9.3 CE) de la ordenanza» y «resultará muy relevante cuando el posterior trámite de audiencia e información pública ex art. 49 b) LBRL se practique de forma incompleta o irregular, dificultando de facto la participación ciudadana». Por ello, entiende que «a los efectos de determinar la posible nulidad de una ordenanza, es relevante valorar el alcance real, en términos de participación ciudadana, que la omisión de la consulta previa ha proyectado sobre cada concreta ordenanza».

A la vista de lo expuesto, fácilmente puede apreciarse la diversidad de posicionamientos doctrinales, con buenos argumentos, que ha originado la omisión, en la LPACAP, de toda previsión acerca de los efectos

\footnotetext{
8 También rechazan esta posibilidad otros autores, como CASADO (2018: 202 y 203) y CIERCO y ROPERO (2017: 128).

9 La cursiva es del autor.

10 La cursiva también es del autor.
} 
REALA. Nueva Época - N. ${ }^{0}$ 14, octubre 2020 - ISSN: 1989-8975 - DOI: https://doi.org/10.24965/reala.i14.10796 - [Págs. 29-48]

Los efectos jurídicos de la omisión del trámite de consulta pública previa en el procedimiento de elaboración de las disposiciones..

que desencadena la ausencia -o práctica inadecuada- de la consulta pública previa en el procedimiento de elaboración de disposiciones de carácter general; y el carácter subsanable o no de la omisión de este trámite con la posterior realización de los trámites de audiencia e información pública. En tanto que, para algunos, la consecuencia no puede ser otra que la nulidad de pleno derecho de la norma reglamentaria afectada, para otros las consecuencias son menos graves, por lo que relativizan su eficacia invalidante. Igualmente, en tanto que para algunos la omisión del deber de consulta previa no puede, en ningún caso, quedar subsanada con la realización posterior de los trámites de audiencia e información pública, para otros esta subsanación resulta admisible. Gran inseguridad jurídica, pues, derivada de una omisión que fácilmente podría haberse evitado incluyendo una previsión específica en la LPACAP.

\section{LOS PRIMEROS PRONUNCIAMIENTOS JURISPRUDENCIALES SOBRE LOS EFECTOS DE LA OMISIÓN DEL TRÁMITE DE CONSULTA PÚBLICA PREVIA}

Ante el silencio de la LPACAP, adquieren gran relevancia las interpretaciones que realicen los tribunales en torno a los efectos aparejados a la omisión o insuficiencia de la consulta pública previa en el procedimiento de elaboración de disposiciones de carácter general. Ciertamente, aún ha transcurrido poco tiempo desde la entrada en vigor de la LPACAP, pero ya existen algunos pronunciamientos del Tribunal Supremo y de los Tribunales Superiores de Justicia de las Comunidades Autónomas que abordan esta cuestión. A ellos nos referimos a continuación.

\subsection{Las primeras Sentencias del Tribunal Supremo}

El Tribunal Supremo ya ha abordado cuestiones relacionadas con la consulta pública en dos Sentencias, con motivo de la resolución en única instancia de dos recursos contencioso-administrativos presentados contra normas reglamentarias estatales, en los que se alegaba por los recurrentes, entre otras cosas, la omisión de la consulta pública previa en el procedimiento normativo y se solicitaba la nulidad de pleno derecho de los reglamentos aprobados. Se trata de las Sentencias núm. 268/2019, de 28 de febrero de $2019^{11}$ y núm. 1719/2019, de 12 de diciembre de 201912. Sin embargo, por los motivos que veremos, todavía no ha llegado a pronunciarse sobre los efectos jurídicos anudados a la ausencia de este trámite participativo.

En la Sentencia núm. 268/2019, de 28 de febrero de 2019, se resuelve el recurso contencioso-administrativo interpuesto por la Junta de Comunidades de Castilla-La Mancha contra la Orden ETU/35/2017, de 23 de enero, por la que se establecen los suplementos territoriales en las Comunidades Autónomas de Cataluña, La Rioja, Castilla-La Mancha y Comunidad Valenciana, en relación con los peajes de acceso de energía eléctrica correspondientes al ejercicio 2013. La Junta de Castilla-La Mancha incluye, entre los diferentes motivos de impugnación que formula, la omisión de la consulta pública previa prevista en el artículo 133 de la LPACAP en el procedimiento de elaboración de la norma impugnada, privando a las personas afectadas por la norma de la posibilidad de pronunciarse sobre la necesidad y oportunidad de su aprobación, sobre su objetivo y las posibles alternativas. Sin embargo, el Tribunal Supremo considera que, en este caso, dada la naturaleza y alcance de la Orden impugnada, no era necesaria la consulta pública previa ${ }^{13}$. En efecto, entiende que «se trata de una Orden de carácter instrumental que incluye los suplementos territoriales a los peajes del año 2013, sin que pueda considerarse un verdadero reglamento ejecutivo de la Ley del Sector Eléctrico»; y que «se ciñe a dar cumplimiento al pronunciamiento de esta Sala en lo relativo a los suplementos territoriales, sin que presente un contenido regulatorio sustantivo que permita considerar que resulten de aplicación las normas procedimentales que corresponden a los reglamentos contemplados en el artículo 133 y ss. de la Ley 39/2015, de 1 de octubre, de Procedimiento Administrativo Común de las Administraciones Públicas». Por ello, «el alegato sobre la omisión del trámite de consulta a los afectados no puede ser acogido, en cuanto no estamos ante un supuesto regulado en el artículo 133 de la ley reseñada, antes bien, ante una Orden acotada a ejecutar lo acordado por este Tribunal Supremo». De este modo, en la medida en que no se considera necesaria aquí la consulta pública previa, no entra a abordar los efectos jurídicos derivados de su omisión.

\footnotetext{
11 Sentencia del Tribunal Supremo núm. 268/2019, de 28 de febrero de 2019 (Sala de lo Contencioso-Administrativo, Sección 3. ${ }^{a}$, recurso núm. 669/2017, ponente: Isabel Perelló Doménech).

12 Sentencia del Tribunal Supremo núm. 1719/2019, de 12 de diciembre de 2019 (Sala de lo Contencioso-Administrativo, Sección 4. ${ }^{\text {a }}$ recurso núm. 194/2018, ponente: M. ${ }^{\text {a }}$ del Pilar Teso Gamella).

13 FJ $4 .^{\circ}$.
} 
REALA. Nueva Época - N. ${ }^{0}$ 14, octubre 2020 - ISSN: 1989-8975 - DOI: https://doi.org/10.24965/reala.i14.10796 - [Págs. 29-48]

Los efectos jurídicos de la omisión del trámite de consulta pública previa en el procedimiento de elaboración de las disposiciones..

En la Sentencia núm. 1719/2019, de 12 de diciembre de 2019, el Tribunal Supremo resuelve el recurso contencioso-administrativo interpuesto por dos sindicatos (la Unión General de Trabajadores y la Confederación Sindical de Comisiones Obreras) contra el Real Decreto 94/2018, de 2 de marzo, por el que se crea la Comisión interministerial para la incorporación de criterios sociales en la contratación pública. También aquí las recurrentes sostienen en el escrito de demanda que se ha vulnerado el artículo 26, apartados 2 y 6, de la Ley 50/1997, de 27 de noviembre, del Gobierno, al no haberse realizado la consulta pública, ni haberse conferido trámite de audiencia a las organizaciones sindicales más representativas de los intereses de los trabajadores, como son los dos sindicatos recurrentes ${ }^{14}$. Sin embargo, aunque en el escrito de demanda se alega esa doble infracción y se hace una mención inicial a la consulta pública, el Tribunal Supremo destaca que en el alegato y exposición razonada se refiere únicamente al trámite de audiencia previsto en el artículo 26.6 de la mentada Ley 50/1997. Por ello, se limita a decir que «el artículo 26 de la citada Ley 50/1997, como también en el artículo 133 de la Ley 39/2015, de 1 de octubre, del Procedimiento Administrativo Común de las Administraciones Públicas, prevén, respecto del procedimiento de elaboración de normas reglamentarias y por lo que hace al caso, dos trámites diferentes. De un lado, un trámite de consulta pública para recabar la opinión de los ciudadanos y organizaciones representativas que tiene lugar antes de la elaboración del proyecto de norma reglamentaria. Y de otro, está el trámite de audiencia que recaba la opinión de aquellos ciudadanos titulares de derechos e intereses legítimos afectados por el proyecto de norma reglamentaria ya redactado, así como de las organizaciones o asociaciones reconocidas por ley que agrupen o representen a las personas cuyos derechos e intereses legítimos se vieran afectados por la norma o cuyos fines guarden relación directa con su objeto» ${ }^{15}$. Y opta por limitar su enjuiciamiento a la falta de audiencia a los sindicatos recurrentes y, por tanto, a la lesión del artículo 26.6 de la Ley 50/1997, a tenor del escrito de demanda, sin abordar la cuestión de la consulta pública previa, sobre la que omite cualquier pronunciamiento. La conclusión a la que llega es la necesidad, en la norma analizada, del trámite de audiencia previsto legalmente, por lo que su omisión, según impone el artículo 47.2 de la LPACAP, determina su nulidad de pleno derecho ${ }^{16}$. Sin embargo, ningún análisis se efectúa, por las razones que hemos apuntado, de los efectos jurídicos derivados de la omisión de la consulta pública previa. Una nueva oportunidad perdida para sentar jurisprudencia.

Por otra parte, ha habido varios intentos frustrados de planteamiento de recurso de casación ante el Tribunal Supremo frente a varias Sentencias del Tribunal Superior de Justicia de Castilla y León que han anulado el Decreto 14/2017, de 27 de julio, de autorización y funcionamiento de los centros de carácter social para la atención a las personas mayores en Castilla y León, entre otros motivos, por la omisión del trámite de consulta pública previa ${ }^{17}$. El Tribunal Supremo considera que no se aclara, en ningún caso, sobre qué particular se precisa de un pronunciamiento jurisprudencial y recuerda que, «en relación con la omisión de trámites en el procedimiento de elaboración de los reglamentos, existe abundante jurisprudencia de esta Sala (contenida, entre otras, en las sentencias de fechas 10 de octubre de 1991 (recurso 658/1990), 14 de octubre de 1992 (recurso 4484/1990), 15 de octubre de 1997 (recurso 1483/1993), 17 de marzo de 2000 (recurso 2686/1996), 19 de febrero de 2002 (recurso 184/1999), 28 de diciembre de 2005 (recurso 5129/2002), 24 de febrero de 2010 (recurso 6861/04), 6 de julio de 2010 (recurso 446/2008) y 23 de enero de 2013 (recurso 589/2011)» ${ }^{18}$. Por ello, se han inadmitido a trámite todos los recursos de casación planteados y no existe, hasta el momento, ninguno admitido en que se plantee como cuestión de interés casacional objetivo sobre la cual deba fijar jurisprudencia el Tribunal Supremo la de los efectos jurídicos derivados de la omisión -o insuficiente realización- del trámite -preceptivo- de consulta pública previa en el procedimiento de elaboración de normas reglamentarias. Sin embargo, no descartamos que pueda ser admitido a trámite

14 En cambio, el Abogado del Estado considera que no se infringe ni el artículo 26.2 ni el artículo 26.6 de la Ley 50/1997, porque no procede el trámite de consulta pública previa, ni el de audiencia a los ciudadanos o las organizaciones o asociaciones reconocidas por la Ley, cuando se trata de reglamentos independientes u organizativos. Además, añade que el Reglamento impugnado es una norma interna de la administración, que alumbra un órgano administrativo, compuesto por personal de la administración, por lo que no se vulnera la libertad sindical, pues ello no afecta ni se conecta con el contenido esencial de ese derecho fundamental.

15 FJ $3 .^{\circ}$ de la Sentencia.

16 Vid. el FJ $7 .^{\circ}$ de la Sentencia

17 Vid. infra el apartado 3.2.4, epígrafe B, de este trabajo.

$18 \mathrm{FJ} 2 .^{\circ}$ de los Autos del Tribunal Supremo de 19 de julio de 2019 (Sala de lo Contencioso-Administrativo, Sección 1. a, recurso núm. 942/2019, ponente: M. ${ }^{\text {a }}$ del Pilar Teso Gamella); de 19 de julio de 2019 (Sala de lo Contencioso-Administrativo, Sección 1. ${ }^{a}$, recurso núm. 1024/2019, ponente: M. ${ }^{a}$ del Pilar Teso Gamella); de 4 de octubre de 2019 (Sala de lo Contencioso-Administrativo, Sección 1. ${ }^{a}$, recurso núm. 1518/2019, ponente: José Luis Requero lbáñez); y de 24 de octubre de 2019 (Sala de lo Contencioso-Administrativo, Sección 1. a , recurso núm. 1025/2019, ponente: José Luis Requero lbáñez). 
REALA. Nueva Época - N. ${ }^{0}$ 14, octubre 2020 - ISSN: 1989-8975 - DOI: https://doi.org/10.24965/reala.i14.10796 - [Págs. 29-48]

Los efectos jurídicos de la omisión del trámite de consulta pública previa en el procedimiento de elaboración de las disposiciones..

en el futuro algún recurso de casación que plantee esta cuestión, si, en el escrito de preparación, se justifica adecuadamente, con suficiencia y con especial referencia al caso, por qué existe interés casacional objetivo en relación con este tema que exija un pronunciamiento por parte del Tribunal Supremo; y se desarrolla un esfuerzo argumental suficiente sobre la trascendencia de este pronunciamiento más allá del caso concreto, poniendo de manifiesto la afección y la previsible influencia de esta doctrina en otros muchos supuestos.

En definitiva, aunque el Tribunal Supremo ha abordado de forma colateral algunas cuestiones relativas al trámite de consulta pública previa regulado en el artículo 133 de la LPACAP, aún no hay ninguna sentencia que aborde la cuestión central que aquí nos ocupa, esto es, la de los efectos jurídicos -invalidantes o no- de la omisión de este trámite preceptivo. Esperemos que en un futuro no muy lejano vuelvan a darse nuevas oportunidades de análisis de esta cuestión que permitan al Tribunal Supremo fijar doctrina clarificadora que ponga fin a la inseguridad jurídica actualmente existente.

\subsection{Las primeras Sentencias de los Tribunales Superiores de Justicia de las Comunidades Autónomas}

Los últimos dos años han visto la luz algunas sentencias de Tribunales Superiores de Justicia que abordan los efectos de la omisión -o práctica inadecuada- del trámite de consulta pública previa en el procedimiento de elaboración de disposiciones de carácter general. Son especialmente relevantes las dictadas por los Tribunales Superiores de Justicia de Aragón, Navarra, Cataluña, Castilla y León, Asturias y Galicia.

\subsubsection{Las Sentencias del Tribunal Superior de Justicia de Aragón núm. 126/2019 y núm. 127/2019, de 28 de marzo de 2019: efectos de la omisión del trámite de consulta pública previa en el procedimiento de elaboración de reglamentos autonómicos}

La Sala de lo Contencioso-Administrativo del Tribunal Superior de Justicia de Aragón ha analizado recientemente los efectos jurídicos derivados de la omisión del trámite de consulta pública previa en dos Sentencias de 28 de marzo de 2019 en que se analizan sendos recursos contencioso-administrativos interpuestos contra el Decreto del Gobierno de Aragón 35/2017, de 14 de marzo, por el que se modifica el Decreto 108/2009, de 23 de junio, por el que se crea el fichero de datos de carácter personal «Registro de Juegos Prohibidos» ${ }^{19}$. Este Decreto se había aprobado sin este trámite, por considerar la administración autonómica que se trataba de una norma meramente organizativa, sin afección a derechos particulares de los ciudadanos ni a la normativa de protección de datos. Sin embargo, los recurrentes discrepan de esta consideración y, en su recurso, entre otros muchos motivos de impugnación ${ }^{20}$, alegan la omisión del preceptivo trámite de consulta previa recogido en el artículo 133 de la LPACA y, por ende, la vulneración del artículo 105.a) de la CE, habida cuenta de que, en su opinión no se trata de una norma de carácter organizativo, sino que afecta a los derechos de los ciudadanos.

Para dar respuesta a este litigio, el Tribunal Superior de Justicia de Aragón empieza analizando la naturaleza jurídica de la norma impugnada y deja claro que se trata de un reglamento ejecutivo que desarrolla la Ley $2 / 2000$, de 28 de junio, del juego de Aragón, por lo que no puede entenderse que este reglamento tenga un carácter exclusivamente organizativo ${ }^{21}$. Al tratarse de una norma no organizativa y con efectos evidentes tanto sobre los clientes de los locales de juego como sobre estos mismos, considera que, con carácter previo al dictamen del Consejo Consultivo ${ }^{22}$, también debía producirse el trámite de consulta pública -además de otros trámites participativos-. Afirma el Tribunal que, al no ser una norma exclusivamente organizativa, «han de respetarse los derechos de participación y consulta previstos en el art. 133 de la Ley 39/2015, de 1 de octubre, de la Ley de Procedimiento Administrativo Común de las Administraciones Públicas, lo que determina la vulneración del art. 105 a) de la Constitución. Igualmente, es preciso reseñar que falta cumplir la audiencia a las organizaciones más representativas cuyos fines guarden relación con el objeto de la disposición (art. 49 de la Ley 2/2009 de 11 de mayo, del Presidente y del Gobierno de Aragón) y el informe de la Comisión del Juego de Aragón, de conformidad a lo dispuesto en el art. 51.1.a) de la Ley 2/2000 de 28 de junio del Juego de Ara-

19 Sentencias del Tribunal Superior de Justicia de Aragón núm. 126/2019 y núm. 127/2019, de 28 de marzo de 2019 (Sala de lo Contencioso-Administrativo, Sección $1 .^{a}$, recursos núm. 133/2017 y 111/2017, ponentes: Juan Carlos Zapata Hijar y Jesús M. ${ }^{a}$ Arias Juana -respectivamente-).

20 Vid. los antecedentes de hecho $5 .^{\circ}$ y $2 .^{\circ}$ de las Sentencias núms. 126/2019 y 127/2019, respectivamente.

21 Vid. los FFJJ $1 .^{\circ}$ y $2 .^{\circ}$ de las Sentencias núms. $126 / 2019$ y $127 / 2019$, respectivamente.

22 Sobre la necesidad del informe del Consejo Consultivo, por tratarse de un reglamento ejecutivo, vid. los FFJJ $2 .^{\circ}$ y $3 .^{\circ}$ de las Sentencias núms. 126/2019 y 127/2019, respectivamente. 
REALA. Nueva Época - N. ${ }^{0}$ 14, octubre 2020 - ISSN: 1989-8975 - DOI: https://doi.org/10.24965/reala.i14.10796 - [Págs. 29-48]

Los efectos jurídicos de la omisión del trámite de consulta pública previa en el procedimiento de elaboración de las disposiciones..

Lucía Casado Casado

gón. Es evidente también que deberá cumplir la normativa de transparencia que ha quedado citada, sin que aprecie la Sala vulneración de norma competencial alguna, por el hecho de que la iniciativa se lleve a cabo por el Departamento competente en juego, dado que el cumplimiento de la materia de protección de datos es transversal a toda acción pública y no competencia de ninguna Departamento en concreto» ${ }^{23}$. En consecuencia, procede a declarar la nulidad de pleno derecho de la norma impugnada, que, en consecuencia, se anula.

\subsubsection{La Sentencia del Tribunal Superior de Justicia de Navarra núm. 88/2019, de 10 de abril de 2019: efectos de la omisión del trámite de consulta pública previa en el procedimiento de elaboración de reglamentos autonómicos}

La Sala de lo Contencioso-Administrativo del Tribunal Superior de Justicia de Navarra ha tenido ocasión de pronunciarse recientemente sobre los efectos de la omisión del trámite de consulta pública previa en el procedimiento de elaboración de disposiciones de carácter general. Lo ha hecho en la Sentencia núm. 88/2019, de 10 de abril ${ }^{24}$, que resuelve el recurso contencioso-administrativo interpuesto por un sindicato -STEE EILAS- contra la Orden Foral 51/2018, de 7 de junio, de la Consejera de Educación, por la que se aprueban las normas de gestión de las relaciones de aspirantes al desempeño, mediante contratación temporal, de puestos de trabajo docentes al servicio del Departamento de Educación.

En el recurso, el sindicato recurrente alega la nulidad de la citada Orden por falta del preceptivo trámite de consulta pública previa, de conformidad con lo señalado por el artículo 133 de la LPACAP. Por su parte, el Gobierno de Navarra se opone a la demanda y, tras recordar que se cumplieron durante la tramitación de esta norma las previsiones de la Ley Foral 11/2012, de 21 de junio, de Transparencia y Gobierno Abierto, considera que no era preciso, en este caso, el trámite de consulta pública previa porque la Orden Foral impugnada es una disposición general organizativa, es decir, con efectos ad intra, en la medida en que regula las relaciones de aspirantes a contratación temporal en educación. Además, señala que fue aprobada antes de la Sentencia del Tribunal Constitucional 55/2018, por lo que resultaba de aplicación el apartado 4 in fine, que permitía omitir la consulta si la propuesta no tiene impacto en la actividad económica ni impone obligaciones relevantes a los destinatarios. A mayor abundamiento, advierte que no nos hallamos ante la elaboración de un proyecto de reglamento, sino ante su mera modificación o revisión puntual para dar cumplimiento a una sentencia previa de la Sala de lo Contencioso-Administrativo del Tribunal Superior de Justicia de Navarra ${ }^{25}$. Por ello, considera que el trámite de consulta no ha sido obviado, ya que el proyecto de Orden Foral fue trasladado a las organizaciones sindicales y sometido a la mesa sectorial, publicado en la web y sometido a información pública. Y, en su opinión, subsidiariamente, considera que no concurre la nulidad de pleno derecho alegada en la demanda y que el defecto sería subsanable, dado que no ha causado indefensión alguna a la parte actora.

Planteada en estos términos la controversia, el Tribunal Superior de Justicia de Navarra entra a analizar las diferentes cuestiones planteadas por las partes. En primer lugar, constata que en la tramitación de la Orden Foral impugnada no consta su sometimiento a consulta pública previa que prevé el artículo 133 de la LPACAP -y tampoco se ha justificado su improcedencia en este caso-, a pesar de que "es una disposición general como se desprende de su propio título y articulado, siendo así que establece con vocación de continuidad, las normas de gestión de las listas de contratación en Educación, por lo que su tramitación ha de observar lo indicado en el artículo citado ${ }^{26}$. En efecto, «(...) la Orden Foral objeto del presente recurso, no comprende aspectos internos o domésticos, característicos y propios de la organización ad intra que corresponde gestionar a la Administración, sino ad extra; estableciendo los criterios para elaborar listas de contratación temporal y por tanto afectando a los ciudadanos que quieren formar parte de las mismas. Es por tanto una norma que precisaba la consulta pública previa del artículo 133 Ley 39/2015» ${ }^{27}$.

En segundo lugar, tampoco considera oponibles las causas de exención del apartado 4 in fine del artículo 133 (falta de impacto económico, no imposición de obligaciones relevantes o regulación parcial), «dado

23 Vid. los FFJJ $3 .^{\circ}$ y $4 .^{\circ}$ de las Sentencias núms. 126/2019 y 127/2019, respectivamente.

24 Sentencia núm. 88/2019, de 10 de abril de 2019 (Sala de lo Contencioso-Administrativo, Sección 1. a , recurso núm. 307/2018, ponente: Ana Irurita Díez de Ulzurrun).

25 Se trata de la Sentencia núm. 337/2017 del Tribunal Superior de Justicia de Navarra (Sala de lo Contencioso-Administrativo, Sección 1. ${ }^{a}$, recurso núm. 325/2016, ponente: M. ${ }^{a}$ Jesús Azcona Labiano), que anula los artículos 3 y 4 de la Orden Foral 55/2016, de 29 de abril, del Consejero de Educación por la que se aprueban las normas de gestión de las relaciones de aspirantes al desempeño mediante contratación temporal de puestos de trabajo docentes al Servicio del Departamento de Educación.

26 FJ $2 .^{\circ}$.

27 FJ $2 .^{\circ}$ 
REALA. Nueva Época - N. ${ }^{0}$ 14, octubre 2020 - ISSN: 1989-8975 - DOI: https://doi.org/10.24965/reala.i14.10796 - [Págs. 29-48]

Los efectos jurídicos de la omisión del trámite de consulta pública previa en el procedimiento de elaboración de las disposiciones...

que fueron declaradas inconstitucionales para las CC.AA, por la STC 55/2018, de 24 de mayo ${ }^{28}$, y no resultaron suficientemente motivadas en el momento de dictarse la Orden Foral impugnada» ${ }^{29}$.

En tercer lugar, dada la naturaleza del trámite de consulta pública previa, considera que su omisión no puede corregirse con el posterior sometimiento a información pública de la norma. Afirma el Tribunal que «la inobservancia del trámite de consulta pública previa no puede ser suplantada por la publicación posterior y sometimiento a información pública y traslado a sindicatos integrados en la mesa sectorial del proyecto de Orden Foral, actuaciones que sí se observaron en cumplimiento de la LF 1/2012 de Transparencia y Gobierno Abierto, pues la consulta pública previa es un trámite anterior y distinto a estos, que pretende cumplir con el objetivo constitucional de lograr la participación ciudadana en la elaboración de las normas recabando con carácter previo a la elaboración la opinión de ciudadanos y empresas acerca de los problemas que se pretenden solucionar con la iniciativa, la necesidad y oportunidad de su aprobación, los objetivos de la norma y las posibles soluciones alternativas regulatorias y no regulatorias» ${ }^{30}$. Por ello, la omisión de la consulta pública «no es susceptible de subsanación, porque tiene la condición de requisito procedimental preceptivo en orden a permitir la participación ciudadana y ha de realizarse con carácter previo a la elaboración de la ley o del reglamento quedando sin finalidad si se tramita una vez aprobada la norma. La consulta previa sólo tiene sentido antes de la elaboración de la ley o del reglamento para facilitar que los potenciales destinatarios realicen aportaciones sobre la misma» ${ }^{31}$.

A la vista de estos razonamientos, el Tribunal concluye que la omisión del trámite de consulta pública conlleva la nulidad de pleno derecho de la Orden Foral 51/2018, de 7 de junio, por vulneración de lo dispuesto en el artículo 133 de la LPACAP. Además, es irrelevante que la omisión de este trámite no haya causado indefensión al sindicato recurrente, que participó en la Mesa sectorial, dado que es un trámite preceptivo y su incumplimiento provoca la nulidad de pleno derecho de la norma ${ }^{32}$.

\subsubsection{La Sentencia del Tribunal Superior de Justicia de Cataluña núm. 588/2019, de 28 de junio de 2019: efectos de la omisión del trámite de consulta pública previa en el procedimiento de elaboración de reglamentos autonómicos}

En la Sentencia núm. 588/2019, de 28 de junio de 201933, el Tribunal Superior de Justicia también ha abordado la cuestión de los efectos de la omisión del trámite de consulta pública previa, a raíz del examen del recurso contencioso-administrativo interpuesto por varias asociaciones ${ }^{34}$ contra el Decreto $73 / 2017$, de 20 de junio, por el que se aprueba el Reglamento del impuesto sobre bebidas azucaradas envasadas. El recurso se fundamenta, entre otros motivos, en la omisión de trámites relevantes en la tramitación del citado Decreto, como son los de participación ciudadana y de consulta pública, así como en su no inclusión en el Plan Anual Normativo correspondiente al año 2017, de acuerdo con lo establecido en la LPACAP. Por el contrario, la Generalitat de Catalunya, en su contestación a la demanda, sostiene la correcta tramitación del Decreto $73 / 2017$, que el mismo es ajustado a derecho y no vulnera ninguna norma legal ni reglamentaria, y que no existe arbitrariedad ni desviación de poder.

El Tribunal Superior de Justicia, para resolver, tras recordar lo dispuesto por los artículos 133 de la LPACAP y 69 de la Ley catalana 19/2014, de Transparencia, Acceso a la Información Pública y Buen Gobierno, en relación con los trámites participativos en el procedimiento de elaboración de normas, trae a colación la doctrina de la Comisión Jurídica Asesora de la Generalitat en relación con la omisión de los trámites de consulta, audiencia e información pública ${ }^{35}$ y la jurisprudencia del Tribunal Supremo sobre los efectos de la

28 El Tribunal Superior de Justicia considera aplicable esta Sentencia a la Orden Foral objeto del litigio, dado que dicha norma no había alcanzado firmeza en el momento de pronunciarse el Tribunal Constitucional (vid. el FJ 2. ${ }^{\circ}$ ).

$29 \mathrm{FJ} \mathrm{2}^{\circ}$

30 FJ $2 .^{\circ}$

31 FJ 2.

32 Vid. el FJ $2 .^{\circ}$

33 Sentencia del Tribunal Superior de Justicia de Cataluña núm. 588/2019, de 28 de junio de 2019 (Sala de lo ContenciosoAdministrativo, Sección 2. ${ }^{a}$, recurso núm. 515/2017, ponente: Jordi Palomer Bou).

34 Asociación Nacional de Grandes Empresas de Distribución (ANGED), Asociación de Cadenas Españolas de Supermercados (ACES), Asociación Española de Distribuidores de Autoservicios y Supermercados (ASEDAS), Federación Española de Industrias de la Alimentación y Bebidas (FIAB), Asociación Española de Codificación Comercial (AECOC), Asociación Empresarial de Marcas de Restauración y Asociación Promarca (PROMARCA).

35 Concretamente, se menciona el Dictamen de la Comisión Jurídica Asesora 151/2017, de 1 de junio, sobre el Proyecto de Decreto por el cual se aprueba el Reglamento del impuesto sobre bebidas azucaradas envasadas (ponente: Joan Pagès i Galtés). Vid. 
REALA. Nueva Época - N. ${ }^{0}$ 14, octubre 2020 - ISSN: 1989-8975 - DOI: https://doi.org/10.24965/reala.i14.10796 - [Págs. 29-48]

Los efectos jurídicos de la omisión del trámite de consulta pública previa en el procedimiento de elaboración de las disposiciones..

omisión de los trámites participativos en el procedimiento de elaboración de disposiciones de carácter general $^{36}$. En particular, apela a lo establecido por el Tribunal Supremo en la Sentencia de 29 de junio de $2017^{37}$ en relación con la omisión del trámite de información pública, como medio para la participación ciudadana en el procedimiento de elaboración de disposiciones administrativas. Considera el Tribunal Supremo que éste es un trámite inexcusable por imperativo de lo establecido en los artículos 9.2 y 105.a) de la Constitución y 86 de la ya derogada Ley 30/1992, de 26 de noviembre, de régimen jurídico de las administraciones públicas y del procedimiento administrativo común (hoy, art. 83 de la LPACAP) ${ }^{38}$. Por ello, su omisión determina la nulidad de pleno derecho de la norma. Sostiene el Tribunal que «el indicado Decreto autonómico 54/2013, es nulo de pleno derecho, ya que, como hemos declarado en nuestra Sentencia de 7 de enero de 2014 (recurso de casación 3345/2010), y constituye doctrina jurisprudencial consolidada (Sentencia de 28 de octubre de 2009 -recurso de casación 3793/2005- entre otras), los defectos procedimentales cometidos en la aprobación de las disposiciones de carácter general, cual es el Decreto autonómico impugnado, tienen trascendencia sustancial, y, en consecuencia, conforme a lo dispuesto en el artículo 62.2 de la citada Ley 30/1992, de 26 de noviembre, acarrean su nulidad radical o de pleno derecho, de manera que el recurso contenciosoadministrativo deducido en la instancia debe ser estimado, según lo establecido concordantemente en los artículos 68.1.b), 70.2, 71.1.a) y 72.2 de la Ley de la Jurisdicción Contencioso-Administrativa» ${ }^{39}$.

A la luz de esta jurisprudencia, constatada la omisión de los trámites de consulta, audiencia e información pública en el procedimiento de elaboración del Decreto impugnado, a pesar de que aparecen expresamente exigidos en la tramitación, concluye que este Decreto es nulo de pleno derecho. En efecto, sostiene que se ha producido la omisión de estos trámites y que no se trata de una simple insuficiencia en la motivación dada para justificar su omisión. En su opinión «no nos encontramos ante una insuficiente motivación, sino que la motivación alegada se aparta de forma evidente de las causas que la propia Ley establece para poder prescindir de tales trámites, puesto que estas se hallan claramente establecidas en la Ley, y por tanto al omitirse tales trámites legalmente exigidos en la tramitación del Decreto recurrido, es por lo que resulta procedente estimar el recurso interpuesto y declarar la nulidad del mismo, por lo que no resulta necesario entrar a examinar los restantes motivos del recurso» ${ }^{40}$.

\subsubsection{Las Sentencias del Tribunal Superior de Justicia de Castilla y León}

También la Sala de lo Contencioso-Administrativo del Tribunal Superior de Justicia de Castilla y León ha abordado ya, en varias ocasiones, la cuestión de los efectos invalidantes derivados tanto de la omisión como de la práctica inadecuada de la consulta pública previa.

\section{A) La Sentencia núm. 574/2018, de 14 de junio de 2018: efectos de la omisión del trámite de consulta pública previa en el procedimiento de elaboración de ordenanzas fiscales}

En la Sentencia del Tribunal Superior de Justicia de Castilla y León núm. 574/2018, de 14 de junio de $2018^{41}$, se aborda una cuestión que se ha evidenciado como una de las más conflictivas por lo que respecta a la aplicación del trámite de consulta pública previa en el ámbito local: la de si este trámite resulta o no exi-

\footnotetext{
el FJ V.4, apartado c), de este Dictamen.

36 Vid. el FJ $3 .^{\circ}$ de la Sentencia.

37 Sentencia del Tribunal Supremo núm. 1145/2017, de 29 de junio de 2017 (Sala de lo Contencioso-Administrativo, Sección 5. recurso núm. 1964/2016, ponente: César Tolosa Tribiño).

${ }_{38}$ En la Sentencia del Tribunal Supremo que se cita se afirma que «Ese carácter ineludible del trámite de información pública en la aprobación de las disposiciones administrativas ha sido remarcado por la doctrina jurisprudencial más reciente, recogida, entre otras, en nuestras Sentencias de fechas 4 de mayo de 2007 (recurso de casación 7450/2007), 10 de diciembre de 2009 (recurso de casación 4384/2005), 28 de junio de 2012 (recurso de casación 3013/2010), 13 de mayo de 2013 (recurso de casación 3400/2009) y 25 de septiembre de 2013 (recurso de casación 6557/2011), habiendo declarado en las dos primeras que el que una ley, en este caso la Ley autonómica gallega 9/2002, de 30 de diciembre, no establezca expresamente el trámite de información pública, no es razón para no exigirlo inexcusablemente al venir impuesto por otras disposiciones con rango de ley, que lo hacen obligatorio para una mejor protección de los intereses generales, constitucionalmente amparados en los artículos 9.2 y 105.a) de la Constitución, 3.5 y 86 de la Ley 30/1992, de 26 de noviembre, y 24.1.c) de la Ley 50/1997, del Gobierno» (vid. el FJ 3. ${ }^{\circ}$ de la Sentencia del Tribunal Superior de Justicia de Cataluña).

$39 \mathrm{Vid}$. el FJ $3 .^{\circ}$ de la Sentencia del Tribunal Superior de Justicia de Cataluña (y 12. ${ }^{a}$ de la Sentencia del Tribunal Supremo).

40 FJ $3 .^{\circ}$ in fine.

41 Sentencia del Tribunal Superior de Justicia de Castilla y León núm. 574/2018, de 14 de junio de 2018 (Sala de lo ContenciosoAdministrativo, Sección 3. ${ }^{\text {a }}$, recurso núm. 548/2017, ponente: Francisco Javier Pardo Muñoz).
} 
REALA. Nueva Época - N. ${ }^{0}$ 14, octubre 2020 - ISSN: 1989-8975 - DOI: https://doi.org/10.24965/reala.i14.10796 - [Págs. 29-48]

Los efectos jurídicos de la omisión del trámite de consulta pública previa en el procedimiento de elaboración de las disposiciones..

gible en la tramitación de las ordenanzas fiscales y, por ende, si su ausencia puede provocar o no la nulidad de pleno derecho de la norma que finalmente se apruebe ${ }^{42}$.

La aplicación de este trámite a las ordenanzas fiscales ha originado discrepancia y disparidad de opiniones desde la aprobación de la LPACAP. Ciertamente, este trámite es de aplicación general a las normas aprobadas por las administraciones locales (Casado, 2018: 175-176; Merino, 2016: 19; Orduña, 2016: 1) ${ }^{43}$. Por una parte, el párrafo primero del apartado 4 del artículo 133 de la LPACAP -declarado conforme con la Constitución en la Sentencia 55/2018, de 24 de mayo, y aplicable a todas las administraciones públicas-, que recoge excepciones a la aplicación de la consulta pública, se refiere expresamente a la administración local. Por otra, no debe olvidarse el carácter básico de la LPACAP y, en particular, de su Título $\mathrm{VI}^{44}$ y que las entidades que integran la administración local, de acuerdo con el artículo 2.1.c) de la LPACAP, integran el ámbito subjetivo de aplicación de esta Ley. No obstante, la disposición adicional $1 .{ }^{a}$ de la propia LPACAP establece que «Los procedimientos administrativos regulados en leyes especiales por razón de la materia que no exijan alguno de los trámites previstos en esta Ley o regulen trámites adicionales o distintos se regirán, respecto a éstos, por lo dispuesto en dichas leyes especiales». Y el Real Decreto Legislativo 2/2004, de 5 de marzo, por el que se aprueba el texto refundido de la Ley Reguladora de las Haciendas Locales (en adelante, TRLRHL), precisamente recoge, en su artículo 17, una regulación específica sobre el procedimiento de elaboración de las ordenanzas fiscales, así como sobre sus requisitos de publicación y publicidad. Es cierto que este precepto, aunque prevé la participación de los ciudadanos en el procedimiento de elaboración de las ordenanzas fiscales, ésta se produce una vez elaborada y aprobada provisionalmente la redacción de la ordenanza fiscal, a través de la exposición pública del acuerdo de aprobación provisional adoptado por la corporación local durante un plazo mínimo de treinta días, dentro de los cuales los interesados pueden examinar el expediente y presentar las reclamaciones que estimen oportunas. No se prevé, por tanto, un trámite de consulta pública previa, previo a la elaboración de la norma y a la existencia de un texto normativo. La cuestión es si el trámite participativo previsto en el artículo 17 del TRLRHL, por su especialidad, excluye, suple o hace innecesaria, en aplicación de la disposición adicional $1{ }^{a}$ de la LPACAP, la consulta pública contemplada en el artículo 133 de esta Ley, o, por el contrario, este trámite debe añadirse a los regulados por el mencionado artículo 17. Y las respuestas que pueden darse a este interrogante pueden ser muy variadas, tal y como evidencian las diversas interpretaciones doctrinales que han ido aflorando. Algunos autores, como Casado (2018: 191), Del Amo (2018: 4-5) y Menéndez (2016: 9), han defendido la aplicación del trámite del artículo 133 de la LPACAP al procedimiento de elaboración de ordenanzas fiscales, entendiendo que este trámite no tiene equivalente en el artículo 17 del TRLRHL, por las diferencias sustanciales que presenta con el trámite participativo allí previsto ${ }^{45}$ y que, por lo tanto, también debe resultar aplicable. Otros, en cambio, como Velasco (2019: 319-320), han sostenido que el trámite de consulta pública previa recogido en el artículo 133.1 de la LPACAP no resulta aplicable a las ordenanzas fiscales, pues en este ámbito resulta de aplicación preferente, conforme a la disposición adicional $1 .{ }^{a}$ de la LPACAP, el TRLRHL, como ley especial por razón de la materia y esta norma no exige una consulta pública previa. Igualmente, han sido diversas las interpretaciones realizadas por los ayuntamientos ${ }^{46}$ y otras administraciones públicas, encontrándose ejemplos tanto de posiciones favorables ${ }^{47}$ como contrarias $^{48}$ a la exigencia del trámite de consulta pública en el procedimiento de elaboración de ordenanzas fiscales.

42 Sobre esta cuestión, vid. el amplio análisis que realizan CASADO (2018: 183-191) y VELASCO (2019: 319-320).

43 Así lo considera también el Tribunal Superior de Justicia de Castilla y León en la Sentencia núm. 574/2018, de 14 de junio de 2018 (Sala de lo Contencioso-Administrativo, Sección 3. ${ }^{a}$, recurso núm. 548/2017, ponente: Francisco Javier Pardo Muñoz), FJ 3.․

44 Vid. supra la introducción de este estudio.

45 Sobre las diferencias entre ambos trámites participativos, vid. DEL AMO (2018: 4).

46 Sobre la práctica de los ayuntamientos en torno a la exigencia o no del trámite de consulta pública previa en el procedimiento de elaboración de ordenanzas fiscales, vid. CASADO (2018: 184), que pone varios ejemplos.

47 Puede destacarse, a estos efectos, un Informe de la Dirección General de Tributos de la Secretaría de Estado de Hacienda, del Ministerio de Hacienda y Función Pública, de 10 de enero de 2018, en el que da respuesta a una cuestión planteada por la Secretaría General de la Federación Española de Municipios y Provincias. Este informe concluye que en el procedimiento de aprobación de ordenanzas fiscales debería incluirse el trámite de consulta pública previa regulado en el artículo 133 de la LPACAP.

48 Por ejemplo, ha mantenido una posición contraria a la exigencia del trámite de consulta pública previa en el procedimiento de elaboración de ordenanzas fiscales el Consell Jurídic Consultiu de la Comunitat Valenciana. Vid. su Dictamen 752/2017, de 21 de noviembre de 2017, emitido a raíz de la consulta facultativa planteada por el Ayuntamiento de Xirivella, relativa a la aplicación de los artículos 132 y 133 de la LPACAP y de la modificación de la Ley 9/2003, de 2 de abril, para la igualdad entre hombres y mujeres, en la tramitación de ordenanzas y de reglamentos de ámbito local, en el que considera que cabría prescindir de este trámite de participación ciudadana en atención a lo establecido en la disposición adicional $1 .^{\text {a }}$ de la LPACAP (en particular, la consideración $5 .^{\text {a }}$ de este Dictamen). Vid. también, en esta misma línea, el Informe del Ayuntamiento de Madrid, redactado por Marta Gómez Alonso, sobre la 
REALA. Nueva Época - N. ${ }^{0}$ 14, octubre 2020 - ISSN: 1989-8975 - DOI: https://doi.org/10.24965/reala.i14.10796 - [Págs. 29-48]

Los efectos jurídicos de la omisión del trámite de consulta pública previa en el procedimiento de elaboración de las disposiciones..

Ante esta disparidad de criterios interpretativos en torno a la exigencia o no del trámite de consulta pública previa en el procedimiento de elaboración de ordenanzas fiscales, debe ser bienvenida la Sentencia objeto de análisis, ya que, por vez primera -hasta donde nosotros sabemos-, se aborda esta cuestión en una Sentencia. El litigio del que trae causa es un recurso contencioso-administrativo interpuesto por la entidad mercantil Aguas de Valladolid, S. A., contra el Acuerdo del Pleno del Ayuntamiento de Valladolid de 6 de junio de 2017, de aprobación definitiva de la Ordenanza fiscal reguladora de la tasa por prestación de los servicios del ciclo urbano del agua que comprende los de abastecimiento, alcantarillado, depuración de agua y control de vertidos. Una de las cuestiones alegadas en el recurso por la demandante es la de incumplimiento del requisito de participación de los ciudadanos previsto en el artículo 133.1 de la LPACAP, al haberse omitido, durante su elaboración, el trámite de consulta pública previa, lo que, en su opinión, generaría la nulidad de pleno derecho de la ordenanza. Por el contrario, el Ayuntamiento de Valladolid se opone a dicho alegato manifestando que, en el ámbito local, ya existía con anterioridad a la LPACAP, un trámite de información pública establecido en el artículo 49 de la LBRL y en el artículo 17 del TRLRHL, trámites cumplidos en el caso objeto de análisis, por lo que resulta, en su opinión, innecesaria la consulta pública. Además, considera que, en todo caso, la ausencia de dicho trámite no puede considerarse como causa de nulidad de pleno derecho de la Ordenanza ${ }^{49}$.

Planteada en estos términos la controversia, el Tribunal Superior de Justicia de Castilla y León, para dar respuesta a las cuestiones suscitadas, parte de la aplicación general del trámite de consulta pública previa, regulado en el artículo 133 de la LPACAP, a la administración local. Ahora bien, también advierte que la disposición adicional $1 .^{\text {a }}$ de esta Ley permite que los procedimientos administrativos regulados en leyes especiales por razón de la materia que no exijan alguno de los trámites previstos en la misma o regulen trámites adicionales o distintos, se rijan, respecto a éstos, por lo dispuesto en leyes especiales. Y recuerda la regulación específica existente en este ámbito en el artículo 17 del TRLRHL, cuya existencia y aplicación preferente, en tanto que ley especial, le lleva a concluir que el trámite de consulta pública previa no es exigible en el procedimiento de elaboración de ordenanzas fiscales y, en consecuencia, su omisión no puede generar la nulidad de pleno derecho de la ordenanza aprobada. En efecto, afirma el Tribunal que «(...) esta Sala no comparte la interpretación con resultado radicalmente anulatorio que postula la recurrente sobre la aplicación al procedimiento de elaboración de las ordenanzas fiscales previsto en el TRLRHL del trámite de consulta pública contemplado en el artículo 133 de la LPACAP, y es que la disposición final primera de ésta es clara en el sentido de que en los procedimientos administrativos regulados en leyes especiales por razón de la materia -como lo es el de elaboración de las ordenanzas fiscales previsto en el TRLRHL, lo que admite la Dirección General de Tributos en su informe- es de aplicación lo dispuesto en la ley especial no sólo para el caso de que ésta contenga trámites adicionales o distintos al de aquélla, sino también cuando no exija alguno de los trámites previstos en la LPACAP, como lo es dicho trámite de consulta pública, todo ello sin perjuicio de que aunque, ciertamente, se trate de trámites distintos, el de exposición pública previsto en el TRLRHL -cumplido por el Ayuntamiento-, en cuanto preceptivo bajo sanción de nulidad de pleno derecho de la Ordenanza (por todas, STS de 15 de noviembre de 2013) y de obligada resolución de las reclamaciones que se presenten, colma, desde luego, la finalidad de participación ciudadana a que responde el trámite, no siempre preceptivo, de consulta e información pública regulado en la LPACAP, receptor de opiniones y no de reclamaciones de obligada resolución ${ }^{50}{ }^{51}$.

aplicación del trámite de consulta pública previa a las ordenanzas fiscales (publicado en el Anuario de Derecho Municipal 2018, págs. 519-525).

49 En su opinión, además de ser innecesaria la consulta pública previa, su ausencia «no puede considerarse como causa de nulidad de pleno derecho de la Ordenanza, al tener meros efectos internos de preparación de la redacción de proyectos de Ordenanzas, no teniendo que ser las opiniones que se manifestasen ni admitidas ni siquiera contestadas, careciendo de efecto vinculante alguno, sin perjuicio de que la actividad regulada no tiene impacto significativo en la actividad económica dado que se trata de una tasa por servicios que ya se venían prestando y abonando por los vecinos en su calidad de usuarios de los distintos servicios del ciclo integral del agua». Vid. el FJ $3 .^{\circ}$ de la Sentencia objeto de análisis.

50 Nótese que el Tribunal Superior de Justicia de Castilla y León considera que el trámite de consulta pública regulado en la LPACAP es solo «receptor de opiniones y no de reclamaciones de obligada resolución». Ciertamente, la LPACAP no incluye previsión alguna sobre los derechos de los participantes ni sobre las obligaciones que nacen para la administración pública en relación con las aportaciones realizadas durante el trámite de consulta pública, lo que ha sido objeto de crítica por la doctrina (CASADO: 2018: 168; y PRIETO: 2016: 368, entre otros).

51 Vid. el FJ $3 .^{\circ}$ de la Sentencia objeto de análisis. Nótese que el Tribunal Superior de Justicia de Castilla y León considera que «la anterior consideración no se desvirtúa por el hecho de que el Ayuntamiento demandado haya dado lugar a dicho trámite con ocasión de la aprobación de la nueva Ordenanza no tributaria que ha de regular las contraprestaciones económicas establecidas coactivamente 
REALA. Nueva Época - N. ${ }^{0}$ 14, octubre 2020 - ISSN: 1989-8975 - DOI: https://doi.org/10.24965/reala.i14.10796 - [Págs. 29-48]

Los efectos jurídicos de la omisión del trámite de consulta pública previa en el procedimiento de elaboración de las disposiciones...

Lucía Casado Casado

B) Las Sentencias núm. 1054/2018, de 22 de noviembre de 2018, núm. 1055/2018, de 23

de noviembre de 2018, núm. 1060/2018, de 23 de noviembre de 2018 y núm. 1067/2018, de 26

de noviembre de 2018: efectos de la práctica inadecuada del trámite de consulta pública previa en el procedimiento de elaboración de reglamentos autonómicos

Los efectos de la omisión del trámite de consulta pública previa en el procedimiento de elaboración de normas reglamentarias autonómicas han sido objeto de examen en cuatro Sentencias del Tribunal Superior de Justicia de Castilla y León, que resuelven varios recursos contencioso-administrativos interpuestos contra el Decreto 14/2017, de 31 de julio de 2017, de autorización y funcionamiento de los centros de carácter social para la atención a las personas mayores de Castilla y León. Se trata de las Sentencias núm. 1054/2018, de 22 de noviembre de $2018^{52}$, 1055/ 2018, de 23 de noviembre de 2018 53 , núm. 1060/2018, de 23 de noviembre de $2018^{54}$ y núm. $1067 / 2018$, de 26 de noviembre de $2018^{55}$, de especial interés, ya que en ellas no se aborda la cuestión de los efectos de la omisión del trámite de consulta pública previa, sino de su práctica inadecuada.

Efectivamente, el Decreto impugnado había sido objeto de consulta pública previa, pero se había realizado de modo inadecuado, al no haberse dado cumplimiento a lo previsto en la normativa. Por una parte, el plazo concedido en el trámite de consulta pública es notoriamente insuficiente. Así lo destaca el Tribunal en las cuatro Sentencias citadas, trayendo a colación las conclusiones a que ya había llegado el Consejo Consultivo de Castilla y León en su Dictamen sobre el proyecto de Decreto impugnado: «es ciertamente escaso el plazo concedido en el trámite de consulta previa y en el trámite de audiencia a través del portal de Gobierno abierto, teniendo en cuenta los que señalan para esos trámites en la Ley 50/1997, de 27 de noviembre, del Gobierno, en la redacción dada por la disposición final tercera de la Ley 40/2015, de 1 de octubre, del Régimen Jurídico del Sector Público, de 15 días naturales y 15 días hábiles, respectivamente, aun cuando carezcan de carácter básico por referirse a la iniciativa legislativa y potestad reglamentaria del Gobierno de la Nación» ${ }^{56}$. Además, considera que «a la Administración le corresponde acreditar los hechos que justifican su proceder, en este caso, los plazos en que ha llevado a cabo la consulta previa y la audiencia pública, lo que no ha hecho porque no consta en el expediente más allá de su propia manifestación en la memoria» ${ }^{57}$. Por otra, el Tribunal también considera que la consulta previa -al igual que la audiencia- no se ha llevado a cabo en la forma legalmente establecida, es decir, posibilitando que los potenciales destinatarios de la norma y quienes realicen aportaciones sobre ella tengan la posibilidad de emitir su opinión, poniendo a su disposición los documentos necesarios, que deben ser claros y concisos y reunir toda la información precisa para poder pronunciarse sobre la materia, tal y como prevé el artículo 133.1 de la LPACAP. Además, la consulta previa debe permitir recabar la opinión de los sujetos y de las organizaciones más representativas potencialmente afectados por la futura norma acerca de los problemas que se pretenden solucionar; la necesidad y oportunidad de su aprobación; los objetivos de la norma; y las posibles soluciones alternativas regulatorias y no regulatorias. Y, en opinión del Tribunal, a la vista del expediente, la información proporcionada sobre el modelo de atención a las personas mayores que se quiere instaurar es prácticamente inexistente, ya que poco se dice sobre los problemas que se pretenden solucionar, sobre la necesidad y oportunidad de esta regulación y sobre los objetivos de la norma; y no se incluye ninguna alternativa posible. Por ello, «pocas aportaciones se pueden hacer con la escasa, por no decir nula, información sobre el modelo que se pretender instaurar» ${ }^{58}$.

-denominadas prestaciones patrimoniales de carácter público no tributario- que se perciban por la prestación de los servicios públicos como el que aquí nos ocupa, de conformidad con el apartado 6 del artículo 20 del TRLRHL añadido por la disposición final 12 de la Ley 9/2017, de 8 de noviembre, de Contratos del Sector Público, con efectos de 9 de marzo de 2018» (FJ 3. ${ }^{\circ}$ ).

52 Sentencia del Tribunal Superior de Justicia de Castilla y León núm. 1054/2018, de 22 de noviembre de 2018 (Sala de lo Contencioso-Administrativo, Sección $1 .^{a}$, recurso núm. 682/2017, ponente: Ana María Victoria Martínez Olalla).

53 Sentencia del Tribunal Superior de Justicia de Castilla y León núm. 1055/2018, de 23 de noviembre de 2018 (Sala de lo Contencioso-Administrativo, Sección $1 .^{a}$, recurso núm. 723/2017, ponente: Ana María Victoria Martínez Olalla).

54 Sentencia del Tribunal Superior de Justicia de Castilla y León núm. 1060/2018, de 23 de noviembre de 2018 (Sala de lo Contencioso-Administrativo, Sección 1. ${ }^{a}$, recurso núm. 798/2017, ponente: Ana María Victoria Martínez Olalla).

55 Sentencia del Tribunal Superior de Justicia de Castilla y León núm. 1067/2018, de 26 de noviembre de 2018 (Sala de lo Contencioso-Administrativo, Sección 1. ${ }^{\mathrm{a}}$, recurso núm. 684/2017, ponente: M. ${ }^{a}$ de la Encarnación Lucas Lucas).

56 FJ $4 .^{\circ}$, apartado 4.2, de las Sentencias núm. 1054/2018, de 22 de noviembre de 2018, núm. 1055/ 2018, de 23 de noviembre de 2018 y núm. 1060/2018, de 23 de noviembre de 2018; y FJ 2. ${ }^{\circ}$, apartado 4.2, de la Sentencia núm. 1067/2018, de 26 de noviembre de 2018 .

57 FJ 4. ${ }^{\circ}$, apartado 4.2, de las Sentencias núm. 1054/2018, de 22 de noviembre de 2018, núm. 1055/ 2018, de 23 de noviembre de 2018 y núm. 1060/2018, de 23 de noviembre de 2018; y FJ 2. ${ }^{\circ}$, apartado 4.2, de la Sentencia núm. 1067/2018, de 26 de noviembre de 2018.

58 FJ $4 .^{\circ}$, apartado 4.2, de las Sentencias núm. 1054/2018, de 22 de noviembre de 2018, núm. 1055/ 2018, de 23 de noviembre de 2018 y núm. 1060/2018, de 23 de noviembre de 2018; y FJ 2. ․, apartado 4.2, de la Sentencia núm. 1067/2018, de 26 de noviembre de 2018. 
REALA. Nueva Época - N. ${ }^{0}$ 14, octubre 2020 - ISSN: 1989-8975 - DOI: https://doi.org/10.24965/reala.i14.10796 - [Págs. 29-48]

Los efectos jurídicos de la omisión del trámite de consulta pública previa en el procedimiento de elaboración de las disposiciones..

Lucía Casado Casado

A la práctica inadecuada de la consulta pública se añaden las deficiencias detectadas en la audiencia, con infracción de lo dispuesto en el artículo 133, apartados 2 y 3 de la LPACAP y también de los artículos 75 y 76 de la Ley 3/2001, de 3 de julio, del Gobierno y de la Administración de la Comunidad de Castilla y León. Esta insuficiencia de los trámites participativos realizados lleva al Tribunal Superior de Justicia de Castilla y León a estimar que se han vulnerado los artículos 133 de la LPACAP y 75 y 76 de la Ley $3 / 2001$, por lo que estima la pretensión principal formulada en los diferentes recursos interpuestos y, en consecuencia, declara nulo de pleno derecho el Decreto 14/2017, de 31 de julio de 2017, de autorización y funcionamiento de los centros de carácter social para la atención a las personas mayores de Castilla y León, de conformidad con lo establecido en el artículo 47.2 de la LPACAP ${ }^{59}$.

\subsubsection{Las Sentencias del Tribunal Superior de Justicia de Asturias núm. 34/2019, de 28 de enero de 2019, y del Tribunal Superior de Justicia de Galicia núm. 75/2020, de 14 de febrero de 2020: efectos de la omisión del trámite de consulta pública previa en el procedimiento de elaboración de ordenanzas fiscales}

La cuestión de los efectos de la ausencia del trámite de consulta pública previa en el procedimiento de elaboración de ordenanzas fiscales ha vuelto a plantearse, más recientemente, en las Sentencias del Tribunal Superior de Justicia de Asturias núm. 34/2019, de 28 de enero de $2019^{60}$, y del Tribunal Superior de Justicia de Galicia núm. 75/2020, de 14 de febrero de 202061. A raíz del examen de los recursos contenciosoadministrativos presentados, respectivamente, contra la Ordenanza Fiscal Número 400, relativa al Impuesto de Bienes Inmuebles, del Ayuntamiento de Oviedo, aprobada definitivamente en sesión extraordinaria del Pleno del Ayuntamiento de fecha 22 de diciembre de 2017; y el acuerdo del Pleno del Ayuntamiento de Vigo, de 28 de noviembre de 2018, por el que se aprueba definitivamente la modificación, para el ejercicio 2019 , de la Ordenanza Fiscal reguladora del Impuesto sobre Bienes Inmuebles, ambos Tribunales Superiores de Justicia se pronuncian sobre esta problemática.

El Tribunal Superior de Justicia de Asturias, al hilo del análisis del recurso interpuesto, debe entrar a determinar si la consulta pública constituye o no un trámite preceptivo para la aprobación de la ordenanza fiscal objeto de impugnación. Al respecto, tras recordar que el artículo 133.4 in fine de la LPACAP permite prescindir de este trámite cuando la propuesta normativa se limite a regular «aspectos parecidos de una anterior», considera que esta situación es precisamente la que se ha dado en el litigio, ya que la ordenanza impugnada constituía la modificación de una anterior. Por ello, la ausencia de la consulta pública previa no conlleva, en este caso, ningún efecto invalidante, al tratarse de uno de los supuestos en que la propia norma permite la excepción ${ }^{62}$.

Por su parte, el Tribunal Superior de Justicia de Galicia, en primer lugar, recuerda que la disposición adicional primera de la LPACAP prevé con carácter general la aplicación de las leyes especiales a los procedimientos administrativos por ellas regulados por razón de la materia, que no exijan alguno de los trámites previstos en la LAPAC o regulen trámites adicionales o distintos, y que el artículo 17 del TRLRHL regula el procedimiento de elaboración y aprobación de las ordenanzas fiscales. En segundo lugar, apela al informe de la Dirección General de Tributos de 19 de enero de 2018, sobre el impacto de la LPACAP en el procedimiento de aprobación de las ordenanzas fiscales y considera que «el trámite de consulta previa establecido en el artículo 133 de la Ley 39/2015, en la medida en que no tiene equivalente en el TRLRHL, dado el carácter ex novo del mismo, no puede considerarse incluido en el trámite de participación ciudadana regulado en el artículo 17 del TRLRHL, pues son dos trámites distintos y que se realizan en dos momentos y formas diferentes, por lo que se concluye que en el procedimiento de aprobación de ordenanzas fiscales debe incluirse el trámite de consulta pública previa regulado en el artículo 133 de la Ley 39/2015». Ahora bien, en la medida en que en el propio informe se excluye este trámite para los casos de modificación de

59 FJ 5. ${ }^{\circ}$ de las Sentencias núm. 1054/2018, de 22 de noviembre de 2018 y núm. 1060/2018, de 23 de noviembre de 2018; y FJ $2^{\circ}$, apartado 5, de la Sentencia núm. 1067/2018, de 26 de noviembre de 2018.

60 Sentencia del Tribunal Superior de Justicia de Asturias núm. 34/2019, de 28 de enero de 2019 (Sala de lo ContenciosoAdministrativo, Sección 1. ${ }^{\text {a }}$, recurso núm. 144/2018, ponente: Jesús M. ${ }^{a}$ Chamorro González).

61 Sentencia del Tribunal Superior de Justicia de Galicia núm. 75/2020, de 14 de febrero de 2020 (Sala de lo ContenciosoAdministrativo, Sección 4. ${ }^{\text {a }}$, recurso núm. 15113/2019, ponente: M. ${ }^{a}$ del Carmen Núñez Fiaño). Sobre esta cuestión, vid. también, con anterioridad, la Sentencia del Tribunal Superior de Justicia de Castilla y León núm. 574/2018, de 14 de junio de 2018, analizada en el epígrafe A) del apartado 3.2.4 de este trabajo.

62 Vid. el FJ $7 .^{\circ}$ de la Sentencia objeto de análisis. 
REALA. Nueva Época - N. ${ }^{0}$ 14, octubre 2020 - ISSN: 1989-8975 - DOI: https://doi.org/10.24965/reala.i14.10796 - [Págs. 29-48]

Los efectos jurídicos de la omisión del trámite de consulta pública previa en el procedimiento de elaboración de las disposiciones..

Lucía Casado Casado

una ordenanza fiscal ya aprobada con anterioridad, por tratarse de una regulación parcial de la materia, considera -y hace mención expresa a las Sentencias ya analizadas del Tribunal Superior de Justicia de Castilla y León núm. 574/2018 y del Tribunal Superior de Justicia de Asturias núm. 34/2019- que éste sería el criterio aplicable al caso objeto de litigio, en el que «se siguió el procedimiento del artículo 17 TRLHL que, desde luego, colma la finalidad de participación ciudadana que inspira los trámites previstos en la LPAC ex novo, por lo que su omisión en ningún caso sería merecedora de una consecuencia como la postulada por la sociedad demandante: la nulidad de pleno derecho de la modificación operada» ${ }^{63}$.

\section{CONSIDERACIONES FINALES}

El silencio de la LPACAP en torno a los efectos jurídicos de la omisión de la consulta pública previa en el procedimiento de elaboración de normas reglamentarias ha desatado una importante incertidumbre e inseguridad jurídica en los operadores jurídicos, dadas las diversas interpretaciones posibles. Esta disparidad interpretativa se ha reflejado en la doctrina administrativista, que, con argumentos sólidos, ha defendido diferentes posicionamientos que hemos tenido ocasión de analizar en este trabajo. Algunos autores abogan por la nulidad de pleno derecho de la norma reglamentaria aprobada con omisión de este trámite; otros, en cambio, a pesar del carácter preceptivo de la consulta, consideran que su ausencia no implica la nulidad absoluta de la norma finalmente aprobada. Incluso no falta quien admite su subsanación mediante otros trámites posteriores, a través de la participación del trámite de audiencia e información pública, y considera que dicha omisión no constituye una inobservancia trascendente, siempre y cuando quede subsanada a través de los trámites participativos indicados. Asimismo, esta disparidad de criterios interpretativos se ha evidenciado en las propias administraciones públicas (estatales, autonómicas y locales) que, como hemos tenido ocasión de analizar, a través de diferentes informes y dictámenes y, con mayor o menor acierto, también han defendido posicionamientos diversos, con argumentos igualmente válidos.

Ante este panorama incierto, la existencia de jurisprudencia clarificadora constituye una necesidad urgente. De nada vale instaurar un trámite participativo tan innovador y avanzado como es la consulta pública previa si nada se dice sobre los efectos de su incumplimiento y no se penaliza su omisión o práctica inadecuada. Afortunadamente, algunas Salas de lo Contencioso-Administrativo (concretamente, las de los Tribunales Superiores de Justicia de Aragón, Cataluña, Castilla y León y Navarra), como hemos tenido ocasión de analizar en el marco de este estudio, ya han tenido ocasión de pronunciarse sobre esta cuestión. Todas ellas lo han hecho en la misma línea, considerando que la omisión -o práctica inadecuada- de este trámite lleva aparejada como consecuencia la nulidad de pleno derecho de la norma aprobada. En nuestra opinión, este criterio es del todo acertado. La ausencia -o insuficiencia- de la consulta pública previa, salvo que esté amparada en una de las causas de excepción previstas en la normativa y esté debidamente justificada y motivada en el expediente, debe ser causa de nulidad de pleno derecho de la norma reglamentaria aprobada. Solo si la consecuencia jurídica es ésta dotaremos de efectividad a un trámite esencial desde la perspectiva de la participación ciudadana, precisamente por el momento temporal en que se produce (antes de que exista un proyecto normativo). Además, con buen criterio, algunos Tribunales Superiores de Justicia, como el de Navarra, tampoco admiten que este trámite pueda ser subsanable con la realización posterior de otros trámites participativos. Admitir dicha subsanación implicaría, en nuestra opinión, devaluar este trámite participativo.

Sin embargo, aunque este es el criterio seguido por los Tribunales Superiores de Justicia, hasta el momento, no existe pronunciamiento alguno del Tribunal Supremo sobre esta cuestión, aunque sería deseable, dado que únicamente a él corresponde la función de fijar jurisprudencia. A pesar de que el Tribunal Supremo ha tenido ocasión de abordar algunas cuestiones relacionadas con la consulta pública, aún no ha tenido la oportunidad de abordar la cuestión central que nos preocupa, esto es, la de los efectos jurídicos derivados de omisión o práctica inadecuada de este trámite. Ojalá pueda hacerlo en un futuro no muy lejano, ya sea con motivo de la resolución de recursos contencioso-administrativos interpuestos contra normas reglamentarias estatales, ya sea con ocasión de la resolución de un recurso de casación admitido a trámite que plantee como cuestión de interés casacional objetivo la de los efectos jurídicos anudados a la ausencia o práctica inadecuada de la consulta pública previa. Solo así quedarán despejadas de una vez por todas las dudas en torno a las consecuencias jurídicas que puedan derivarse de la aprobación de normas reglamentarias que

$63 \mathrm{Vid}$. el FJ $4 .^{\circ}$ de la Sentencia objeto de análisis. 
REALA. Nueva Época - N.o 14, octubre 2020 - ISSN: 1989-8975 - DOI: https://doi.org/10.24965/reala.i14.10796 - [Págs. 29-48]

Los efectos jurídicos de la omisión del trámite de consulta pública previa en el procedimiento de elaboración de las disposiciones...

Lucía Casado Casado

han obviado, o realizado de forma inadecuada, este trámite. Hasta que ese momento llegue, esperemos que las Salas de lo Contencioso-Administrativo de los Tribunales Superiores de Justicia vayan siguiendo la senda iniciada por los de Aragón, Cataluña, Castilla y León y Navarra.

\section{REFERENCIAS BIBLIOGRÁFICAS}

ANTELO MARTíNEZ, A. R. (2016): "Elaboración de disposiciones de carácter general en la Administración Local, tras la entrada en vigor de la Ley 39/2015", en Revista de Estudios de la Administración Local y Autonómica (REALA). Nueva Época, núm. 6, págs. 105-121. Fecha de consulta: 01-04-2020. URL: https://revistasonline.inap.es/index. php/REALA/article/view/10391/11011. DOI: https://doi.org/10.24965/reala.v0i6.10391.

ARAGUÀS GALCERÀ, I. (2016): "La participación ciudadana en la elaboración de disposiciones generales: estado de la cuestión y perspectivas de futuro tras la aprobación de la Ley 39/2015, de 1 de octubre, de Procedimiento Administrativo Común de las Administraciones Públicas", en Revista Andaluza de Administración Pública (RAAP), núm. 96, págs. 85-126. Fecha de consulta: 01-04-2020. URL: http://www.juntadeandalucia.es/ institutodeadministracionpublica/publico/publicaciones.filter?step=read\&cu $=25 \& c d=500$.

ARAGUÀS GALCERÀ, I. (2017): "La nulidad de los reglamentos por defectos en la realización de los trámites participativos", en LÓPEZ RAMÓN, F.; VILLAR ROJAS, F. (coords.): El alcance de la invalidez de la actuación administrativa. Actas del XII Congreso de la Asociación Española de Profesores de Derecho Administrativo, págs. 487-498. La Laguna, 3 y 4 de febrero de 2017, Madrid: Instituto Nacional de Administración Pública. 1. ${ }^{a}$ ed.

ARAGUÀS GALCERÀ, I. (2019): "La consulta previa en el procedimiento de elaboración de reglamentos autonómicos", en Revista Catalana de Dret Públic, núm. 58, págs. 97-111. Fecha de consulta: 07-04-2020. URL: http://revistes.eapc.gencat.cat/index.php/rcdp/article/view/10.2436-rcdp.i58.2019.3170. DOI: http://dx.doi. org/10.2436/rcdp.i58.2019.3170.

CAMPOS ACUÑA, M. ${ }^{a}$ C. (2016): "Capítulo VIII. La iniciativa legislativa y la potestad reglamentaria", en GALLARDO CASTILLO, M. ${ }^{a}$ J. (dir.): Aproximación al nuevo procedimiento administrativo común de la Ley 39/2015: reflexiones y claves para su aplicación, págs. 565-606. Granada: Centro de Estudios Municipales y de Cooperación Internacional (CEMCI) (Temas de Administración Local). 1. ${ }^{a}$ ed.

CASADO CASADO, L. (2017): "La incidencia de la Ley del Procedimiento Administrativo Común de las Administraciones Públicas sobre la potestad normativa local", en Revista Vasca de Administración Pública (RVAP), núm. 107-I, págs. 87-141. Fecha de consulta: 07-04-2020. URL: https://dialnet.unirioja.es/servlet/ articulo?codigo $=5972507$.

CASADO CASADO, L. (2018): "La aplicación del trámite de consulta pública previa en el procedimiento de elaboración de normas locales dos años después de su entrada en vigor", en Revista Aragonesa de Administración Pública, núm. 52, págs. 159-210. Fecha de consulta: 01-04-2020. URL: http://bibliotecavirtual.aragon.es/bva/i18n/ publicaciones/numeros_por_mes.cmd?idPublicacion=18205\&anyo=2018.

CIERCO SEIRA, C.; ROPERO VILARÓ, A. (2017): "La consulta pública previa en la elaboración de normas reglamentarias", en Anuario del Gobierno Local (Ejemplar dedicado a: Participación ciudadana y regeneración política. Retos de la gestión de los servicios públicos y de los derechos sociales), núm. 1, págs. 93-129. URL: https://www.gobiernolocal.org/anuario-del-gobierno-local-2017/.

DEL AMO GALÁN, Ó. (2018): “Ordenanzas fiscales y consulta pública previa”, en Carta Tributaria. Revista de Opinión, núm. 38, págs. 1-5.

FERNÁNDEZ FERRARONS, M. (2020): El procediment d'elaboració de les ordenances locals a la llum de la millora de la regulació. Barcelona: Atelier (Colección Atelier Administrativo). 1. a ed.

GALÁN CÁCERES, J. (2020): "Contratos menores y procedimiento de elaboración de ordenanza en la Administración local", en Revista CEFLegal. Revista práctica de Derecho, núm. 230, págs. 148-166.

GARCÍA RUBIO, F. (2017): "La potestad reglamentaria local tras la nueva Ley de Procedimiento Común", en Cuadernos de Derecho Local (QDL), núm. 44, págs. 83-131. URL: https://www.gobiernolocal.org/cuadernosderecho-local-no-43-2/.

GARCÍA RUBIO, F. (2020): El derecho local tras la «racionalización». Entre la transparencia, la remunicipalización y el ajuste presupuestario. Valencia: Tirant lo Blanch (Colección Monografías). 1. a ed.

MENÉNDEZ ALONSO, J. M. ${ }^{a}$ (2016): "La elaboración de ordenanzas y reglamentos con la Ley $39 / 2015$ del procedimiento administrativo común: problemática local”, en El Consultor de los Ayuntamientos y de los Juzgados. Revista técnica especializada en Administración Local y Justicia Municipal, núm. 22.

MERINO ESTRADA, V. (2016): "Calidad en la regulación y participación ciudadana en las ordenanzas y reglamentos locales", en Revista de Estudios Locales. CUNAL, núm. 191, págs. 10-21.

MESEGUER YEBRA, J. (2016): "Capítulo 4. Procedimiento de elaboración de normas y better regulation en el ejercicio de la potestad reglamentaria local”, en CAMPOS ACUÑA, M. a C. (dir.): El nuevo procedimiento administrativo local tras la Ley 39/2015, págs. 125-150. Las Rozas (Madrid): Wolters Kluwer, El Consultor de los Ayuntamientos. $1 .^{\text {a }}$ ed. 
REALA. Nueva Época - N.o 14, octubre 2020 - ISSN: 1989-8975 - DOI: https://doi.org/10.24965/reala.i14.10796 - [Págs. 29-48]

Los efectos jurídicos de la omisión del trámite de consulta pública previa en el procedimiento de elaboración de las disposiciones...

Lucía Casado Casado

MIR PUIGPELAT, O. (2017): “¿Better regulation o marketing? La nueva regulación básica del procedimiento de elaboración de reglamentos y normas con rango de ley", en VELASCO RICO, C. I. (dir.): Reflexiones sobre la reforma administrativa de 2015. Análisis crítico de las Leyes de Procedimiento Administrativo Común y de Régimen Jurídico del Sector Público, págs. 209-244. Madrid-Barcelona-Buenos Aires-Sao Paulo: Marcial Pons, 1. ${ }^{a}$ ed.

MORA RUIZ, M. (2016): "Capítulo IX. Iniciativa legislativa y potestad reglamentaria. Disposición derogatoria", en GOSÁlBEZ PEQUEÑO, H. (dir.): La nueva Ley del Procedimiento Administrativo Común. Las Rozas (Madrid): Wolters Kluwer, El Consultor de los Ayuntamientos. 1. ${ }^{\text {a }}$ ed.

ORDUÑA PRADA, E. (2016): "Sobre la potestad normativa local y la Ley del Procedimiento Administrativo Común de las Administraciones Públicas", en Actualidad Administrativa, núm. 2.

PRIETO ROMERO, C. (2016): "El nuevo procedimiento para la iniciativa legislativa y el ejercicio de la potestad reglamentaria”, en Revista de Administración Pública (RAP), núm. 201, págs. 335-372. Fecha de consulta: 07-042020. URL: http://www.cepc.gob.es/publicaciones/revistas/revistaselectronicas? IDR=1\&IDN=1371\&IDA=37944. DOI: $h$ ttp://dx.doi.org/10.18042/cepc/rap.201.14.

PRIETO ROMERO, C. (2019): "El procedimiento de elaboración de ordenanzas por las entidades locales", en Revista Digital CEMCI, núm. 43, págs. 1-39. Fecha de consulta: 07-04-2020. URL: https://revista.cemci.org/numero-43/.

VELASCO CABALLERO, F. (2019): "Elaboración de Ordenanzas y Ley de Procedimiento Administrativo Común", en Revista Vasca de Administración Pública (RVAP), núm. 113, págs. 299-349. Fecha de consulta: 01-04-2020. URL: https://apps.euskadi.eus/t59auUdaWar/R2/t59auEjemplares/page. 